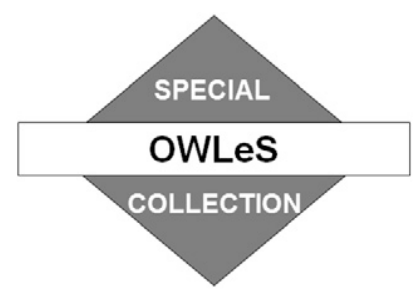

\title{
Thunderstorm Characteristics during the Ontario Winter Lake-Effect Systems Project ${ }^{\mathscr{O}}$
}

\author{
SCOTT M. STEIGER \\ Department of Atmospheric and Geological Sciences, State University of New York at Oswego, Oswego, New York
}

TYLER KRANZ

National Weather Service, Bismarck, North Dakota

THEODORE W. LETCHER

Terrestrial and Cryospheric Sciences Branch, Cold Regions Research and Engineering Laboratory, Hanover, New Hampshire

(Manuscript received 30 June 2017, in final form 18 January 2018)

\begin{abstract}
The Ontario Winter Lake-Effect Systems (OWLeS) field campaign during the winter season of 2013/14 provided unprecedented data with regard to the structure and behavior of long-lake-axis-parallel (LLAP) lake-effect storms. One of the interesting characteristics of LLAP storm bands is their ability to initiate lightning. The OWLeS datasets provide an opportunity to examine more thoroughly the kinematics and microphysics of lake-effect thunder-snowstorms than ever before. The OWLeS facilities and field personnel observed six lake-effect thunderstorms during December-January 2013/14. Most of them produced very little lightning (fewer than six cloud-to-ground strokes or intracloud pulses recorded by the National Lightning Detection Network). The 7 January 2014 storm had over 50 strokes and pulses, however, which resulted in 20 flashes over a 6-h period (0630-1230 UTC), making it the most electrically active storm during the field campaign. Relative to the 18 December 2013 storm, which only had three flashes, the 7 January 2014 case had a deeper boundary layer and greater instability. Also, $45 \%$ of the lightning during the 7 January storm was likely due to flashes initiated by wind turbines or other man-made antennas, along with all of the lightning observed during 18 December. No lightning was documented over Lake Ontario, the primary source of instability for these storms.
\end{abstract}

\section{Introduction}

\section{a. Lake-effect storms and OWLeS}

During the winter of 2013/14, scientists from 11 institutions gathered in upstate New York to conduct a first-of-its-kind field campaign on Lake Ontario-generated lake-effect snowstorms: the Ontario Winter Lake-Effect Systems (OWLeS; Kristovich et al. 2017) project. The University of Wyoming King Air (UWKA) aircraft, heavily instrumented for in situ and remote sensing of

Supplemental information related to this paper is available at the Journals Online website: https://doi.org/10.1175/JAMC-D-170188.s1.

Corresponding author: Scott Steiger, scott.steiger@oswego.edu the atmosphere; three Doppler-on-Wheels (DOW) radars; five rawinsonde systems (four of which were mobile); and the University of Alabama in Huntsville Mobile Integrated Profiling System (MIPS) were some of the key facilities used to study lake-effect storms. The key objectives were focused in three areas: structure, dynamics, and electrification of long-lake-axis-parallel (LLAP; Steiger et al. 2013) storms, upwind and downwind causes and effects of lake-effect systems, and orographic influences on these storms.

Lake-effect storms [Niziol et al. (1995) describe typical organizations] occur when a continental/maritime polar $(\mathrm{cP} / \mathrm{mP})$ air mass is modified via heat and moisture fluxes by a large body of water (in this case, Lake Ontario), leading to the development of moist convection. The surface-based convective cloud tops generally range between 1 and $4 \mathrm{~km}$ above ground level (AGL), and the 
storms form in bands that are approximately $10-25 \mathrm{~km}$ wide and parallel to the mean boundary layer wind direction.

\section{b. Lake-effect lightning}

Winter lightning has been observed in both synopticscale systems [e.g., the northwest quadrant of an extratropical cyclone, mainly associated with elevated convection (Market et al. 2002; Rauber et al. 2014)] and mesoscale surface-based convective storms [e.g., lake effect (Moore and Orville 1990; Steiger et al. 2009) and sea effect (Rakov and Uman 2003, chapter 8)]. Lightning occurring when surface temperatures are cold (i.e., $\leq 0^{\circ} \mathrm{C}$ ) is perceived as unusual, but the fundamental conditions for charge separation (MacGorman and Rust 1998, chapter 3) are possible in both elevated convection and surface-based storms. Diagnosing synoptic/ mesoscale environments that are conducive to lake-effect lightning has been difficult. A few key predictors for initiation of lake-effect lightning include strong (likely convective) updrafts (vertical velocity $w>5 \mathrm{~m} \mathrm{~s}^{-1}$; Michimoto 1991; Zipser 1994), substantial supercooled liquid water concentrations within the lake-effect clouds $\left(>0.1 \mathrm{~g} \mathrm{~m}^{-3}\right)$, mixed hydrometeor types, and substantial depth $(>1 \mathrm{~km})$ of the cloud layer from $-10^{\circ}$ to $-25^{\circ} \mathrm{C}$ [Steiger et al. (2009) referred to this as the likely charging layer in lake-effect storms]. Schultz (1999) observed a lack of convective available potential energy (CAPE) in soundings launched over land near lake-effect storms. Given the obvious convective nature of lake-effect storms, it follows logically that CAPE is present over the lakes during these storms, even though to the authors' knowledge no such overlake soundings have been launched to date. Furthermore, Schultz (1999) noted a fairly electrically active storm in Oswego, New York, in January of 1994 when the warmest temperature in the entire troposphere was $-20^{\circ} \mathrm{C}$, implying minimal supercooled liquid water.

Moore and Orville (1990) were the first to thoroughly examine lake-effect thunderstorms over the Great Lakes through case studies. They found that lake-effect lightning was most commonly observed during intense, single-banded storms (i.e., LLAP) and typically fewer than 30 cloud-to-ground (CG) flashes were initiated. One lake-effect rainstorm on 22-24 September 1983 had nearly 700 flashes over Lakes Erie and Ontario (referred to as the eastern/lower Great Lakes). A surface trough propagated within approximately $100 \mathrm{~km}$ of these storms, suggesting a synoptic-scale interaction that could have deepened the planetary boundary layer, favoring deeper clouds and lightning. All storms occurred during the September-December period during the Moore and Orville study, consistent with the climatological record of peak lake-effect thunderstorm occurrence across the lower Great Lakes (Steiger et al. 2009). The results from Moore and Orville (1990) and Steiger et al. (2009) show that, on average, five of these storms occur each season over the eastern Great Lakes.

More than $75 \%$ of CG flashes observed in the storms Moore and Orville (1990) studied were of positive polarity, not including the anomalous 22-24 September 1983 storm, in which $71 \%$ of the flashes had negative polarity. Market et al. (2002) showed that, outside of the Great Lakes region, lightning is mostly of negative polarity $(80 \%)$ in winter storms.

Lake-effect CG lightning is most prevalent over the waters of Lakes Erie and Ontario and in general does not extend farther than $20 \mathrm{~km}$ inland in lake-effect storms (e.g., Fig. 2 in Steiger et al. 2009). The instability is largest near the surface of the lakes (greatest lowlevel lapse rates); hence, lightning is typically confined to areas over the lakes in these situations. More recent work has shown that, once they move inland, lake-effect clouds make a transition from convective type to more of a stratiform nature (Veals and Steenburgh 2015; Minder et al. 2015).

\section{c. Self-initiated and lightning-triggered upward lightning}

The large Maple Ridge Wind Farm, located downwind of Lake Ontario, may have had an impact on the lightning observed during the OWLeS project. Thunderstorms have recently been noted to initiate upward lightning originating from tall anthropogenic structures [Warner et al. 2014 (snowstorm); Montanyà et al. 2014 (warm season); Kingfield et al. 2017]. These flashes are fundamentally different from the typical downward CG lightning involving stepped leaders originating from the cloud, by which taller objects are also more likely to be struck. It is thought that there are two types of upward lightning that strike these tall objects: lightning-triggered upward lightning (LTUL; Wang et al. 2008; Lu et al. 2009; Warner et al. 2012) or selfinitiated upward lightning (SIUL; Wang and Takagi 2012). LTUL events are preceded by discharge activity near the object; SIUL events, as implied by their name, do not have a preexisting flash in the nearby environment. When ambient wind speeds are strong $\left(>8 \mathrm{~m} \mathrm{~s}^{-1}\right)$, SIUL can occur on a stationary object (e.g., a tower). If the blade on a wind turbine is rotating, SIUL can occur at lower wind speeds as a result of the blade tip "running away" from generated corona space charge (Montanyà et al. 2014), exposing the tip to a stronger local electric field.

SIUL flashes appear to be most frequent during the cold season. For example, close to $80 \%$ of the SIUL 
flashes observed by Zhou et al. (2012) occurred during the nonconvective (cool) season. One hypothesis for this is that cloud charge centers are closer to the tower tops during the winter months when freezing levels and cloud bases [towers frequently penetrate into the clouds (Diendorfer et al. 2009)] are nearer the ground (Montanyà et al. 2014). Lightning detection networks such as the National Lightning Detection Network (NLDN; Cummins and Murphy 2009) classify the processes involved with these upward positive leaders as negative polarity.

A prominent example of wintertime SIUL was the storm sometimes called the Chicago blizzard (Warner et al. 2014). The NLDN recorded 282 flashes [CG and intracloud (IC)] from Oklahoma to Michigan during 1-2 February 2011. Most of these flashes were of negative polarity and ceased to occur once the storm moved over Lake Michigan even though the lake enhanced the precipitation. Warner et al. (2014) provide evidence that these flashes were mostly SIUL flashes associated with a variety of anthropogenic structures.

The purpose of this paper is to characterize the mesoscale and microphysical aspects of lake-effect thundersnow events using the high-resolution OWLeS observations. Lightning was reported (by humans and/ or automated lightning detection systems) during six OWLeS storms: 11, 12, 16, and 18 December 2013 and 7 and 27 January 2014 [intensive observation periods (IOP) 2, 3, 4, 5, 7, and 22, respectively]. In section 2, the OWLeS datasets used in this analysis are discussed. In section 3, the meso- and storm-scale structures of two lightning-producing events (IOP5 on 18 December 2013, with a low flash count, and IOP7 on 7 January 2014, with a high flash count) are compared. In section 3 we also provide evidence for wind-farm-initiated lightning on the Tug Hill Plateau downwind of Lake Ontario. Sections 4 and 5 present a discussion and list of conclusions, respectively.

\section{Data and methods}

The NLDN (Cummins and Murphy 2009; Murphy and Nag 2015) detects both CG lightning strokes and IC lightning pulses (hereby collectively referred to as lightning "events"). One CG flash can have multiple return strokes, and many pulses can compose an IC flash. The network has a CG flash detection efficiency (FDE) of more than $90 \%$ and a median location accuracy of better than $300 \mathrm{~m}$. We do not know if the FDE is different for lake-effect storms versus other storms. Cloud FDE is estimated to be $50 \%-60 \%$ (Murphy and Nag 2015). No minimum peak current thresholds were used in CG definitions for this study (e.g., Cummins and Murphy 2009).
We manually grouped the NLDN CG stroke and IC pulse data (provided by Vaisala, Inc.) into CG/IC flashes via the grouping algorithm described in Cummins et al. (1998). Assuming an event was a CG stroke/IC pulse, we counted the next event as part of the "flash" if it was within $500 \mathrm{~ms}$ of the previous event and $10 \mathrm{~km}(20 \mathrm{~km}$ for IC pulses) of the first event. The maximum duration of the flash was $1 \mathrm{~s}$. Some CG flashes contained IC pulses within them but were still categorized as CG flashes as long as one CG stroke was part of the flash. These methods are similar to those that were used by Warner et al. (2014) for wintertime lightning data (NLDN).

To compare and contrast the storm structures observed during IOP5 and IOP7, data from four facilities deployed during OWLeS were used: 1) four vertically pointing Metek Meteorologische Messtechnik GmbH Micro Rain Radar-2 (MRR) units aligned in a westeast-oriented transect to the east of Lake-Ontario [Minder et al. (2015) give details on the MRR configuration and data postprocessing procedures],2) the MIPS (Karan and Knupp 2006; http://vortex.nsstc.uah.edu/ mips/), 3) mobile rawinsondes [the State University of New York (SUNY) at Oswego team launched Vaisala rawinsondes; the University of Utah team launched Graw Radiosondes GmbH model DFM-09 rawinsondes at the North Redfield (NR) site in Redfield, New York], and 4) the UWKA-mounted (Wang et al. 2012) Wyoming Cloud Radar (WCR) when available. There are no UWKA data available for IOP5 because there was no flight conducted for this storm. The data from the MIPS were collected at Sandy Creek, New York, in close proximity to the Lake Ontario shoreline (Fig. 1) about $50 \mathrm{~km}$ west of where most of the lightning occurred during both IOP5 and IOP7. The UWKA data used to obtain maximum observed updraft speeds during IOP7 were also more than $50 \mathrm{~km}$ from where most of the lightning occurred since we used a flight leg over Lake Ontario. This flight leg was flown approximately $1 \mathrm{~h}$ after the last detected NLDN flash, which provided us with the UWKA data closest to the time period of past lightning. It is fortunate that hightemporal-resolution data from the four MRRs (their geographic locations are shown in Fig. 1) were available for both storms at points within $\sim 10 \mathrm{~km}$ of where the lightning occurred, during the period of lightning.

Two additional important parameters that were analyzed include vertically integrated liquid water and water vapor amounts, which aid in assessing the presence of supercooled water in the lake-effect clouds. These data were collected at Sandy Creek and were made available at 1-min intervals during both IOP5 and IOP7 using the MIPS Microwave Profiling Radiometer [MPR; see Karan and Knupp (2006) for details]. In situ probes [Gerber Scientific, Inc., Particle Volume Monitor 


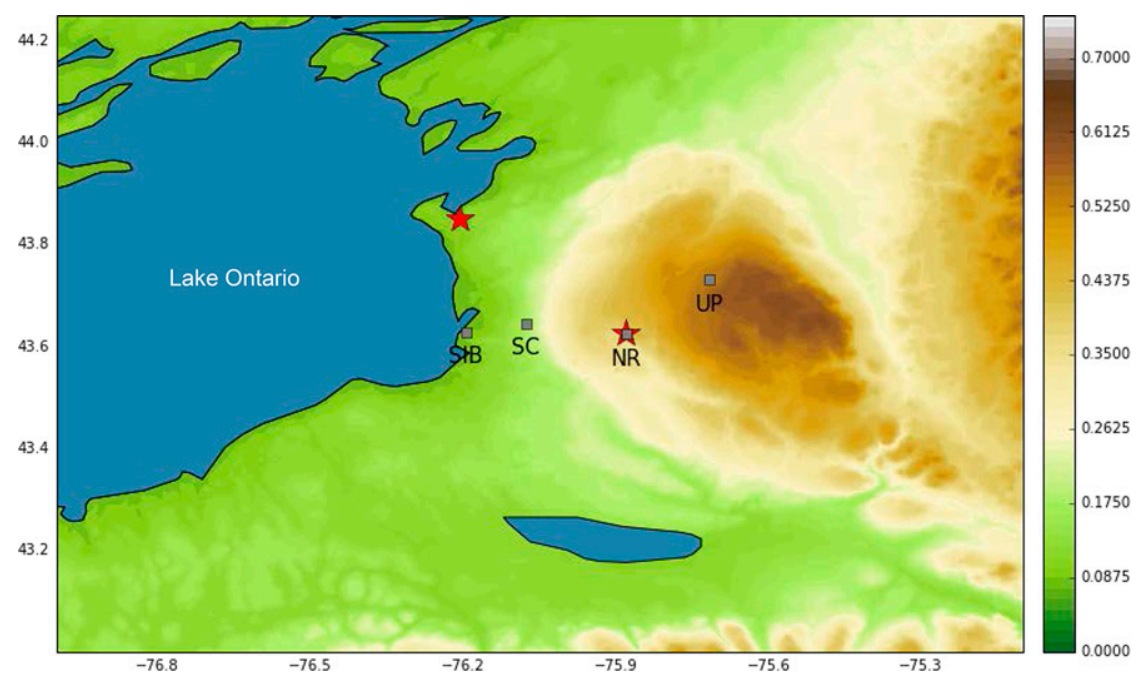

FIG. 1. Region of interest for this study, showing topography (km MSL) and locations of relevant facilities. The MRR transect is shown, where SIB = the Sandy Island Beach site, $\mathrm{SC}=$ the Sandy Creek site, NR = the North Redfield site, and UP = the Upper Plateau site (Tug Hill plateau). The stars denote where relevant rawinsonde observations were taken (the Henderson Harbor site and NR).

(PVM) and Cloud Droplet Probe (CDP)] aboard the UWKA provided local in-cloud measurements of liquid water content (LWC).

Last, the depth of the charging layer (Steiger et al. 2009) within the lake-effect snow clouds was determined with the rawinsondes (2015 UTC 18 December 2013 and 0815 UTC 7 January 2014) at NR. This layer was defined where liquid relative humidity $\mathrm{RH}_{\text {liquid }}$ was near or greater than $80 \%$ and hence relative humidity for ice $\mathrm{RH}_{\text {ice }}$ was near $100 \%$ where temperatures $T$ were between $-5^{\circ}$ and $-40^{\circ} \mathrm{C}$. This layer was expanded to include $T \geq-40^{\circ} \mathrm{C}$ in contrast to the Steiger et al. criterion $\left(\geq-25^{\circ} \mathrm{C}\right)$ because substantial supercooled liquid water was observed by the UWKA in IOP7 when $T<-25^{\circ}$ C. Also, Fig. 12 in Saunders et al. (2006) shows rimer charging occurring at temperatures $\leq-5^{\circ} \mathrm{C}$.

\section{Results}

\section{a. Lake-effect lightning during the entire OWLeS field phase}

Six IOPs with lake-effect thunderstorms $(2,3,4,5,7$, and 22) occurred during the OWLeS field campaign of 42 days (an average frequency of one per week). We only expected to observe one of these thunderstorms during the entire field campaign on the basis of the climatological work done to prepare the OWLeS National Science Foundation grant proposal. Thirty-two CG strokes and 32 IC pulses were recorded by the NLDN during these six IOPs, resulting in 26 flashes (20 CG and 6 IC). The strokes and pulses were evenly distributed between December and
January. Eighty percent of all CG strokes lowered negative charge to ground [very different than the preference for positive flashes observed in Moore and Orville (1990)]. All of the lightning was observed over land, mostly over $30 \mathrm{~km}$ away from the shoreline.

\section{b. IOP5 (18 December 2013)}

\section{1) Mesoscale overview}

IOP5 was the first OWLeS lake-effect storm with multiple flashes of lightning. The evolution of the storm structure during IOP5 is summarized by plan position indicators of base reflectivity measured by the Montague, New York, WSR-88D (KTYX; Fig. 2). The storm began as a broken band of convection during the morning [a mesovortex had just made landfall before 1600 UTC; the center of the vortex is between Sandy Creek, New York (SC), and the upper Tug Hill plateau (UP) in Fig. 2a]. The band shifted south between 1700 and 1800 UTC (Fig. 2b) and then returned north along a west-east orientation by 2000 UTC (Fig. 2c). A surprising thing is that the band contracted to a width of less than $5 \mathrm{~km}$ and intensified near the eastern shoreline around 2300 UTC during a time when because of a descending inversion the environment became less conducive to convection (Fig. 2d). Land breezes may have strengthened this band, however, because they become more intense at night. It was around this time that multiple human reports of lightning occurred, although these reports were not detected by the NLDN. These events may have been small/weak IC flashes that were 
16:00:04 UTC

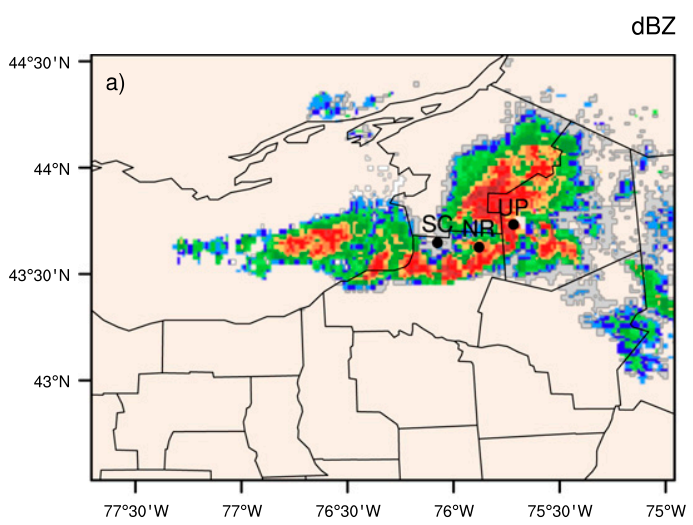

20:03:40 UTC

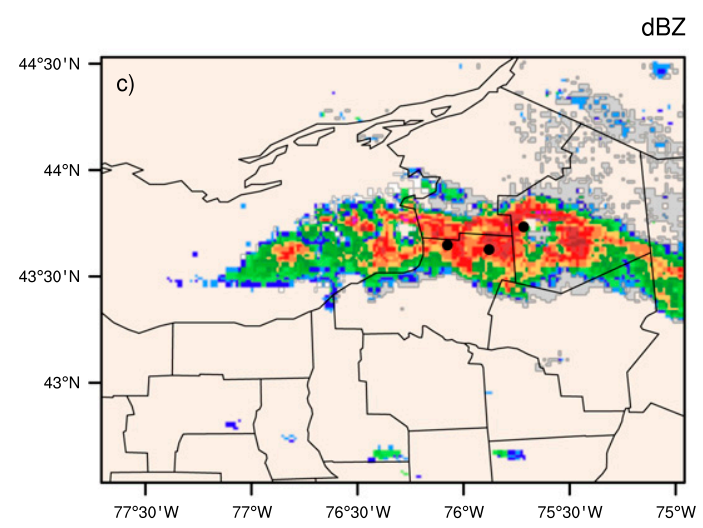

$B Z$
18:04:42 UTC

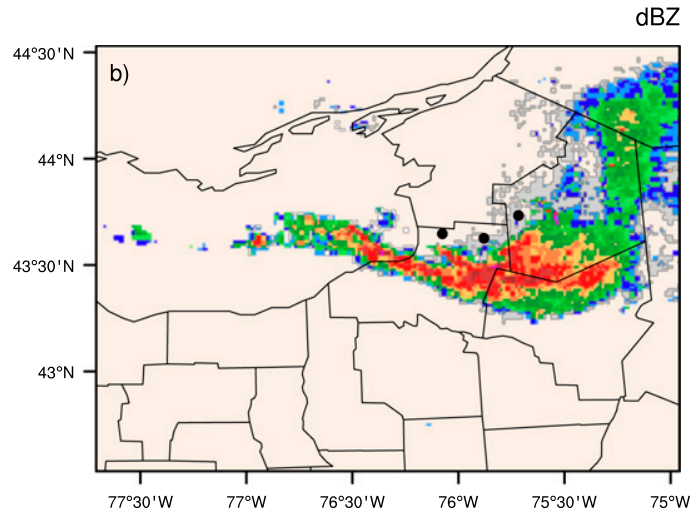

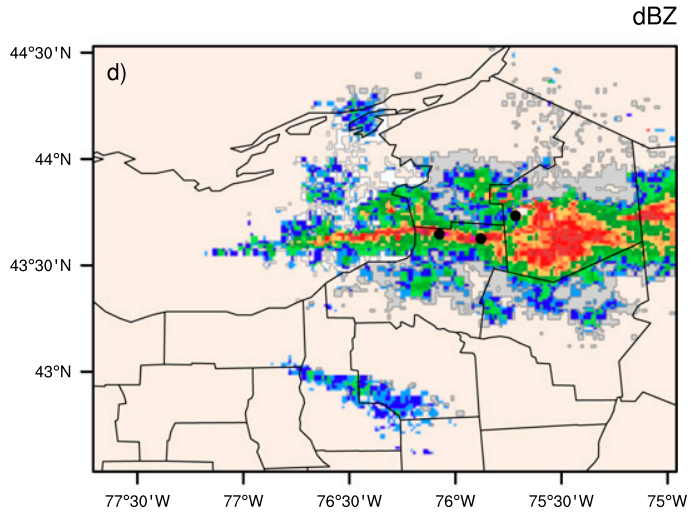

$\mathrm{dBZ}$

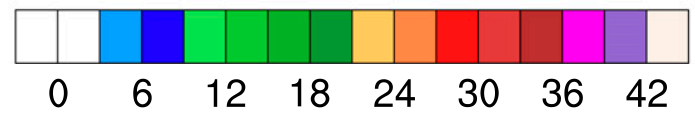

FIG. 2. KTYX base reflectivity (dBZ) for 18 Dec 2013 (IOP5) at the various times shown. The inland MRR transect sites (SC, NR, and UP, as in Fig. 1) are shown.

not detected by the NLDN because of the lower detection efficiency for IC lightning.

IOP5 occurred during a climatologically favorable time of year for lake-effect lightning (Steiger et al. 2009). The 850$\mathrm{hPa}$ temperatures were approximately $-10^{\circ} \mathrm{C}$, and the wind at this level was westerly at $35 \mathrm{kt}\left(17.5 \mathrm{~m} \mathrm{~s}^{-1}\right)$ (Fig. 3; NR site). Surface temperatures were near $-5^{\circ} \mathrm{C}$ on the Tug Hill plateau and were near $0^{\circ} \mathrm{C}$ closer to the lakeshore at lower elevations (per a sounding at Henderson Harbor, New York; not shown). The in-cloud charging layer was $2790 \mathrm{~m}$ deep (Table 1), and the boundary layer top was $700 \mathrm{hPa}$ ( $2.8 \mathrm{~km}$ MSL; Fig. 3$)$. The boundary layer is defined here as the layer in which the atmosphere is well mixed (the temperature profile is nearly adiabatic) from the ground up to a level at which the atmosphere becomes much more stable (e.g., an inversion). To determine instability, we calculate lake-induced (LI) convective indices using a method that is similar to that in Minder et al. (2015). An initially saturated parcel with a temperature equal to the average between the lake areal mean surface temperature and the lowest-level upwind observed sounding temperature (initial parcel temperature $=1.9^{\circ} \mathrm{C}$ ) is lifted in the environment following the upwind observed sounding. The calculated LI-CAPE and LI equilibrium level (LI-EL) values were $300 \mathrm{~J} \mathrm{~kg}^{-1}$ and $2.3 \mathrm{~km}$ MSL, respectively. The upwind sounding was launched from Darlington, Ontario $\left(43.87^{\circ} \mathrm{N}, 78.78^{\circ} \mathrm{W}\right.$; on the northwest shore of Lake Ontario), Canada.

\section{2) IOP5 STORM KINEMATICS, MICROPHYSICS, AND LIGHTNING}

In qualitative terms, IOP5 was a very convective storm (i.e., scattered cells of KTYX reflectivity maxima 


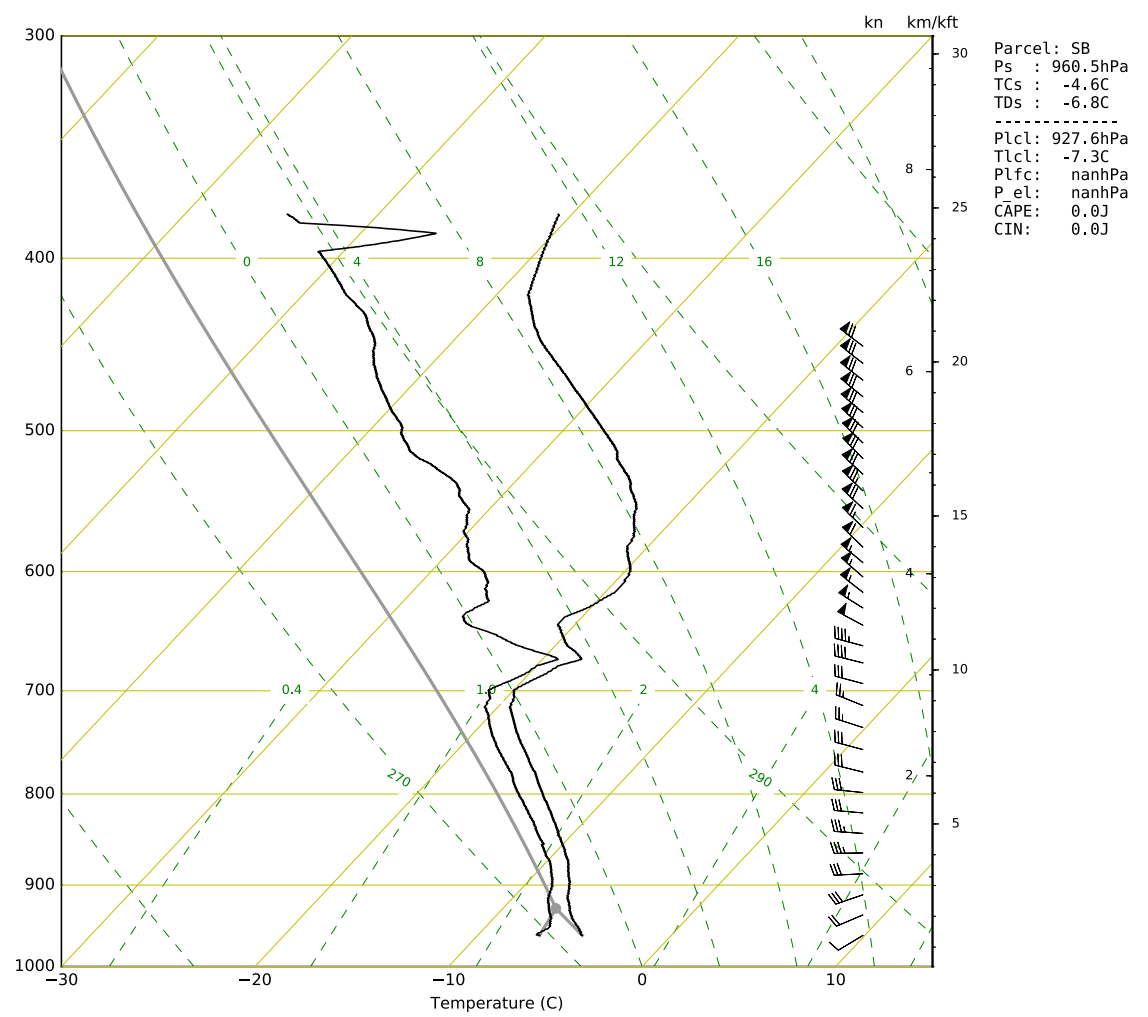

FIG. 3. Sounding (on a skew $T$ - $\log p$ diagram) from NR (in the band; refer to Fig. 2c) launched by the University of Utah team at 2015 UTC 18 Dec 2013 (IOP5). This launch was $2 \mathrm{~h}$ before lightning occurrence and $30 \mathrm{~km}$ away. The lifted surface parcel path is also shown (gray line).

of 35-40 dBZ and frequent graupel reports). The NLDN detected a total of three CG strokes and one IC pulse between 2206 and 2220 UTC, all having negative polarity (Fig. 4). These were grouped into three CG flashes with the algorithm that is described in section 2 . Of interest is that none of the lightning occurred over the lake; rather, all of the lightning occurred on the eastern side of the Tug Hill plateau and in very close proximity to wind turbines ( $<300 \mathrm{~m}$ away).

MRR transect data were analyzed with time-height diagrams as a source of observed reflectivity and vertical motions. Not only did all of these locations collect data in the lake-effect snowband during the period of lightning, but two sites also provided data in close proximity

TABLE 1. Characteristics of lake-effect storms for IOP5 (18 Dec 2013) and IOP7 (7 Jan 2014). The depth of the charging layer includes a temperature range between $-5^{\circ}$ and $-40^{\circ} \mathrm{C}$. See the text for more detailed descriptions, especially for the lightning types (flash type IC* is defined in section $3 \mathrm{~d}$ ).

\begin{tabular}{lcc}
\hline \hline & IOP5 & IOP7 \\
\hline Wmax from MRR transect data $\left(\mathrm{m} \mathrm{s}^{-1}\right)$ & $\sim 4$ (at SIB at 1515 UTC) & $\sim 4$ (at UP at 0915 UTC) \\
Wmax from UWKA-WCR data $\left(\mathrm{m} \mathrm{s}^{-1}\right)$ & No UWKA flight & $\sim 7$ (over lake at 1349 UTC) \\
Max obs vertically integrated liquid water via MIPS MPR data (mm) & 1.95 (at SC at 2248 UTC) & 0.24 (at SC at 0847 UTC) \\
Max obs vertically integrated water vapor via MIPS MPR data (mm) & 7.1 (at SC at 2312 UTC) & 2.2 (at SC at 0906 UTC) \\
Max cloud- (echo-) top height via MRR data (km MSL) & 3.0 & 3.4 \\
Predominant surface hydrometeor type & Graupel & Dendrites \\
Depth of charging layer at NR (m) & 2790 & 2610 \\
No. of CG strokes & 3 & 25 \\
No. of IC pulses & 1 & 28 \\
No. of natural CG flashes & 0 & 8 \\
No. of natural IC flashes & 0 & 3 \\
No. of IC* flashes & 0 & 3 \\
No. of LTUL/SIUL/DPL flashes & 3 & 6 \\
\hline
\end{tabular}




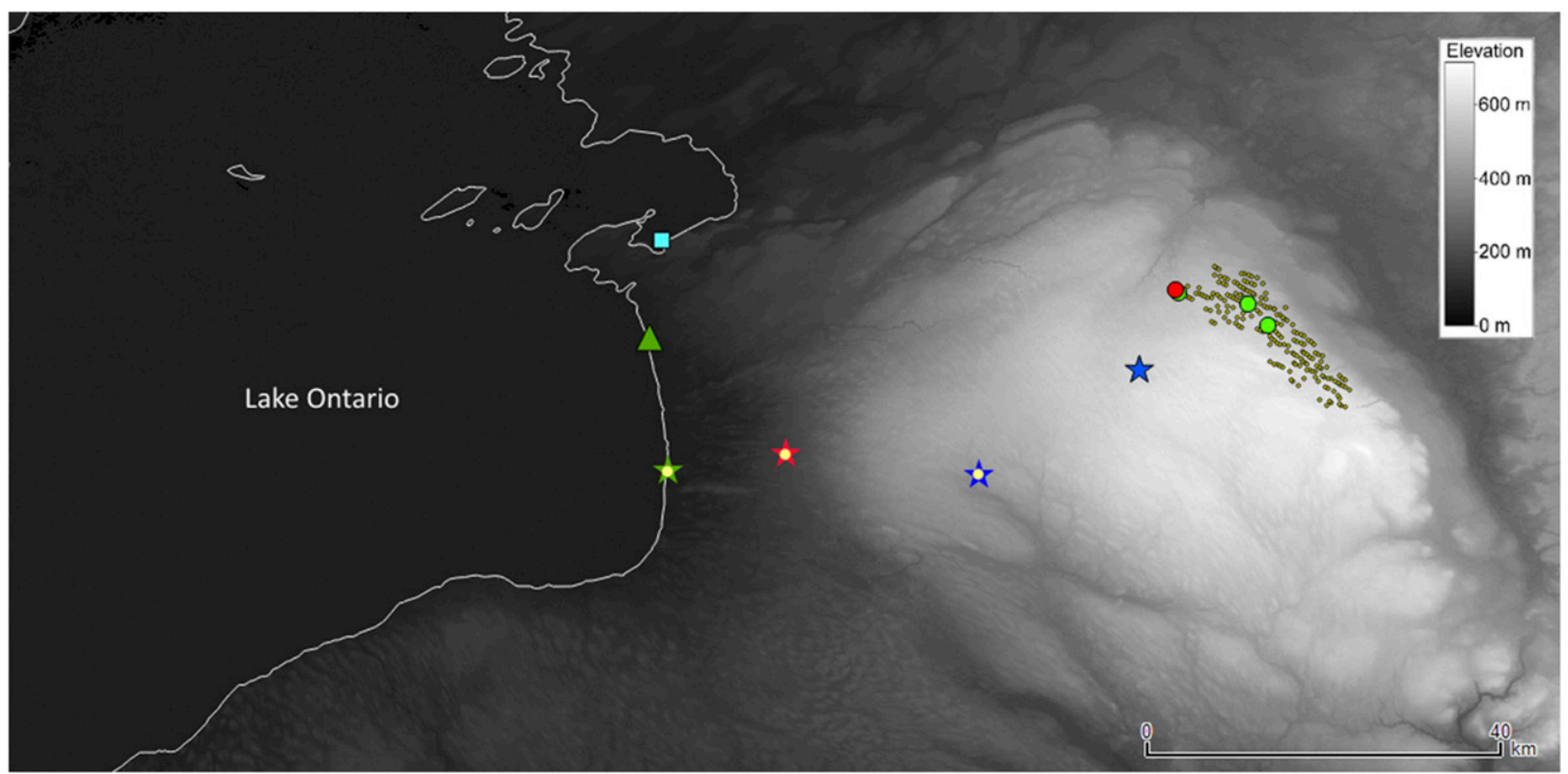

FIG. 4. NLDN-detected lightning events during IOP5 (18 Dec 2013) overlaid on topography (m). The larger green and red points denote CG strokes and IC pulses, respectively (all over the Maple Ridge Wind Farm). The smaller yellow dots represent each of the 195 wind turbines at Maple Ridge Wind Farm. The stars represent the locations of the MRRs (Fig. 1); in addition, the blue star with an interior circle indicates the location of the NR soundings (Figs. 3 and 10), the red star with circle indicates the MIPS location, and the light blue square is the location of the Henderson Harbor sounding as described in the text. The green star with circle and the green triangle indicate DOW radar locations.

to the lightning, in particular the UP site. The timeheight diagrams show the highly convective nature of this IOP [Fig. 5 (reflectivity) and Fig. 6 (radial velocity)]. Convective activity is implied by the highly variable "cellular" appearance of the MRR reflectivity data. By assuming a snow particle terminal velocity of $\sim 1 \mathrm{~m} \mathrm{~s}^{-1}$, a first-order estimate of air velocity is obtained. From this we find that updraft/downdraft air speeds that are near $2 \mathrm{~ms}^{-1}$ were observed frequently, with the strongest air motion observed near the lake at the Sandy Island Beach State Park site (SIB) and at SC. We also loosely identify convective activity as short-lived maxima $\left(<10 \mathrm{~min}\right.$ ) in positive radial velocity $V_{R}$ (upward particle motion; red colors in Fig. 6) adjacent to short-lived negative $V_{R}$ (downward motion; blue colors). These vertical updrafts/downdrafts typically extended throughout the depth of the storm $(\sim 2 \mathrm{~km})$, especially at SIB. Vertical motions weaken and storm depth decreases as one moves inland along the transect, which is indicative of a convective-to-stratiform transition. It is interesting that all of the lightning was observed nearest to the UP MRR, far from the most convective elements of the storm.

The storm reorganized into a small, solid LLAP band around 2250-2300 UTC after the lightning occurred at UP (Fig. 2d) during a descending capping inversion according to nearby OWLeS soundings (not shown). It was at this time that a student observer reported periods of heavy graupel and thunder nearer to the lake at SC (not detected by the NLDN). MRR data show that this was a period of relatively intense convection at SC (Figs. 5, 6).

To understand the bulk vertical storm structure and how it changes along the MRR transect, MRR data are organized into contoured-frequency-by-altitude diagrams (CFAD; Yuter and Houze 1995). Figure 7 shows CFADs of reflectivity data measured during IOP5 at two locations, SC (near shore) and NR (inland, nearer the lightning). For this analysis, we use the same bin size $\left(200 \mathrm{~m}\right.$ and $\left.1.5 \mathrm{~dB} Z_{e}\right)$ and normalization procedures as in Minder et al. (2015). The SC and NR MRRs sampled the core of the lake-effect band multiple times, especially between 1500 and 0000 UTC. The median reflectivity increased with decreasing height at the inland location (NR) and was greatest near the ground (14 dBZ $Z_{e}$; Fig. 7a). (Note these reflectivity values cannot be directly compared with KTYX observations because they are different-wavelength radars: S vs $\mathrm{K}$ band.) In contrast, the median reflectivity peaked near $1.6 \mathrm{~km}$ MSL followed by a small steady decline with decreasing height closer to the shore (SC; maximum of $17 \mathrm{~dB} Z_{e}$ ). This result implies precipitation growth of falling hydrometeors occurred closer to the ground at NR, or a lack of precipitation loss via sublimation. The maximum interquartile range was similar at both MRRs, which is 


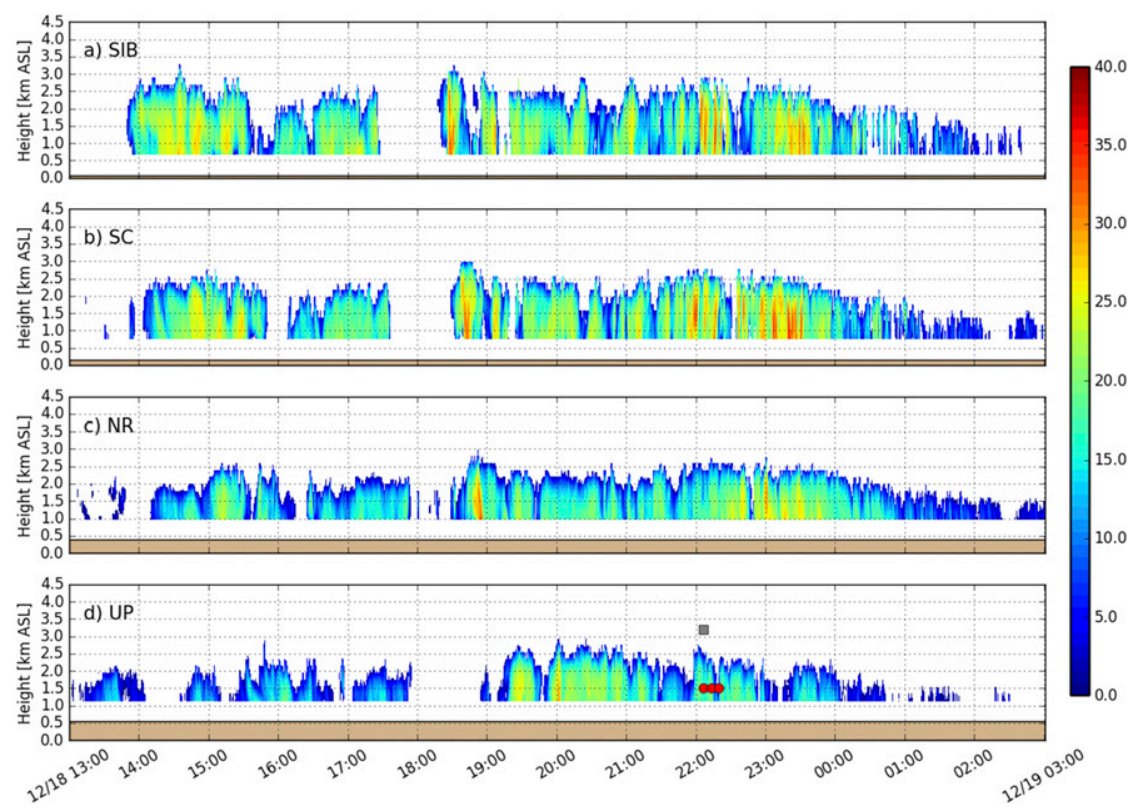

FIG. 5. Time-height plots of equivalent radar reflectivity factor for IOP5 shown for each of the four MRR transect locations, beginning with the westernmost location at SIB (on the lakeshore) and ending with the UP location. Data are averaged to 10 -s time (note that this is equivalent to a horizontal resolution of $140 \mathrm{~m}$ using a cell translational velocity of $14 \mathrm{~m} \mathrm{~s}^{-1}$ as estimated from DOW data) and 200-m vertical resolution. The occurrences of IC and CG lightning are shown by the gray square and red dots, respectively. Their altitudes have no meaning, and they are only shown for the site at which the lightning was closest (within $40 \mathrm{~km}$ ).

not in line with the general relationship found by Minder et al. (2015). Figure 7b shows that the total frequency of echoes $>5 \mathrm{~dB}_{e}$ was greater below $1.9 \mathrm{~km} \mathrm{MSL}$ at NR than at SC, which suggests that more-stratiform-type precipitation processes occurred farther inland [as based on interpretations of similar data by Minder et al. (2015) and assuming that both stations sampled the band for the same amount of time, which is a valid assumption

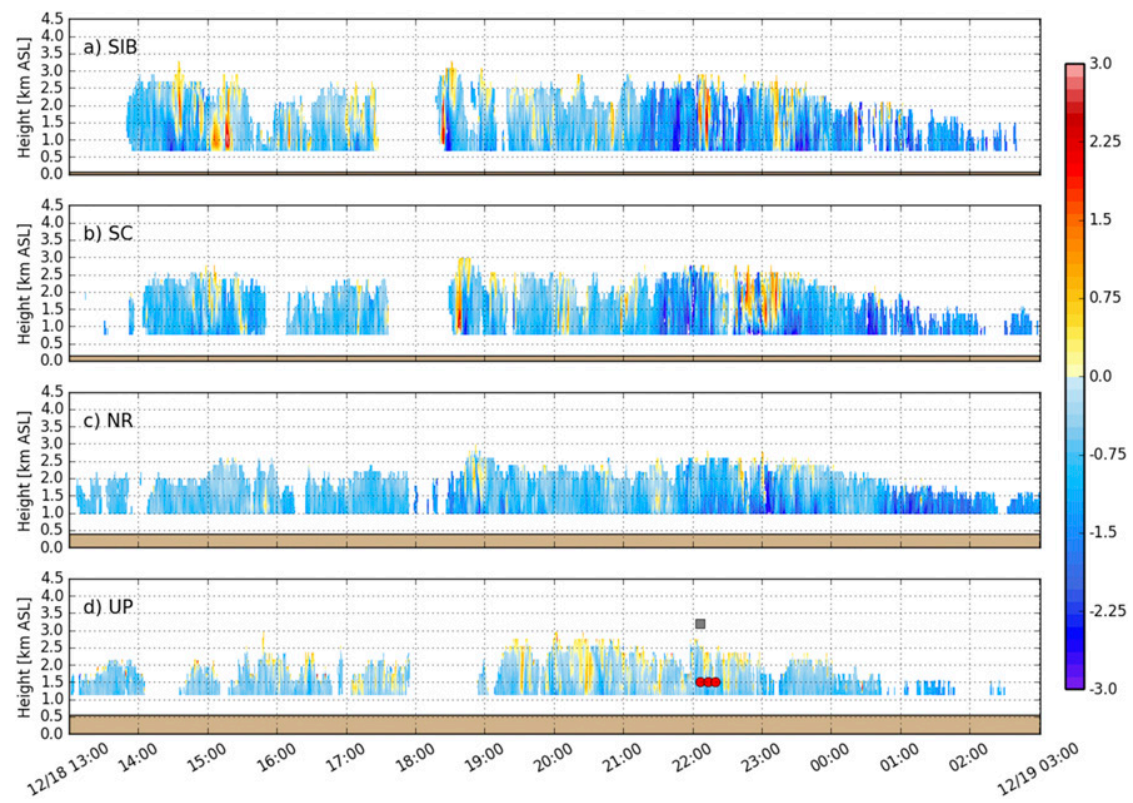

FIG. 6. As in Fig. 5, but for MRR Doppler radial velocity $V_{R}$. Red shows upward particle motion, and blue shows downward particle motion. 

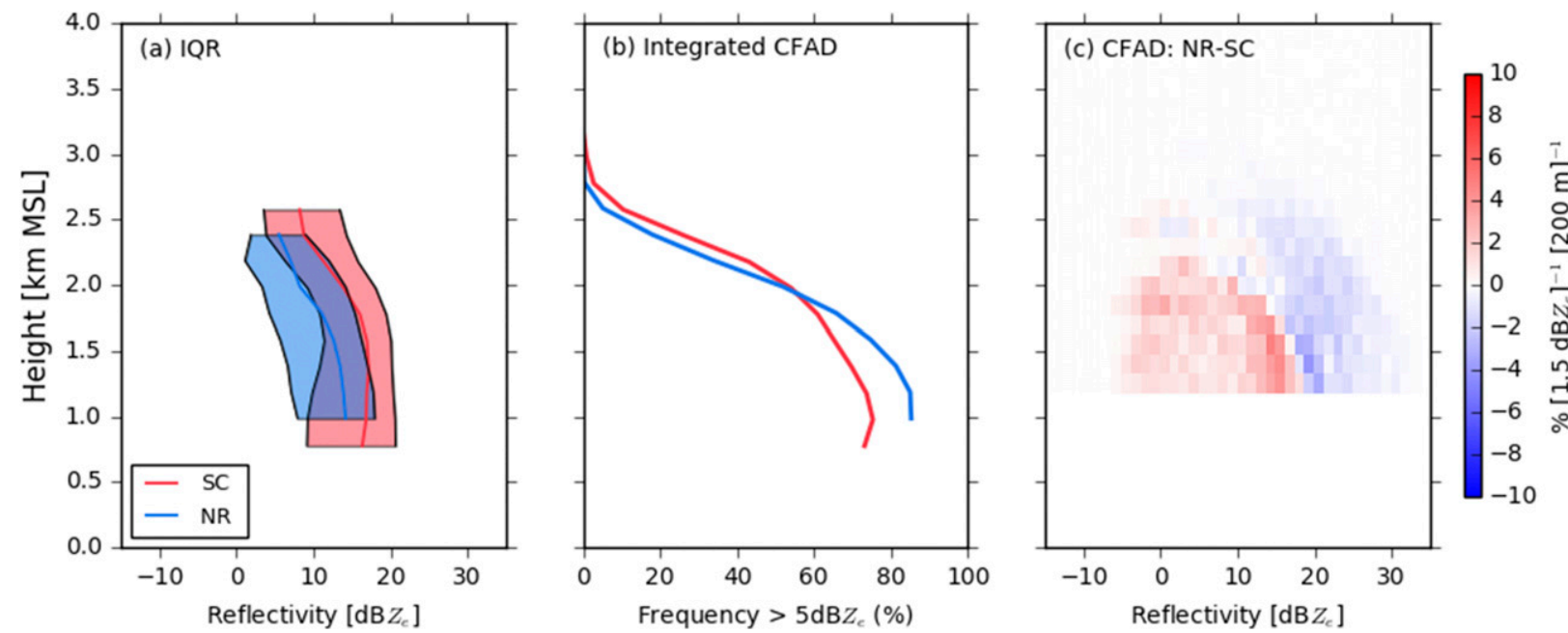

FIG. 7. Comparison of the vertical distribution of MRR $Z_{e}$ during IOP5 at SC and NR (inland): (a) median and interquartile range, (b) total frequency of $>5 \mathrm{~dB} Z_{e}$, and (c) the difference between CFADs (NR - SC). The bin size is $200 \mathrm{~m} \times 1.5 \mathrm{~dB} Z_{e}$. All CFAD values have been normalized by the total number of observation times in the analysis period, giving units of percentage frequency per bin size. For (c), both the SC and NR profiles have been interpolated to a common vertical grid.

when comparing Figs. 5b and 5c]. The total frequency decreases quickly above this level at NR, and there are more echoes at SC at higher altitudes. The CFAD difference shown in Fig. 7c shows an asymmetric dipole structure, similar to that found by Minder et al. (2015). The stronger echoes were more frequent at SC throughout the storm's depth while a broad region from approximately -7 to $16 \mathrm{~dB} Z_{e}$ and from near ground level to $2 \mathrm{~km}$ MSL had more echoes at NR (i.e., more, but weaker echoes overall than at SC). This analysis further verifies that lightning was observed in a region of the storm band with more similarities to stratiform precipitation processes than to convective processes.

The UP site was the closest MRR to where the lightning occurred during IOP5 (within $15 \mathrm{~km}$; see Fig. 4), but this MRR did not observe the band for the same duration as did the SC and NR MRRs (cf. Figs. 5b-d). Figure 8 shows that the UP reflectivity profile was substantially weaker than that at SC (a greater difference than between NR and SC; Fig. 7). The frequency of echoes $>5 \mathrm{~dB} Z_{e}$ was less at UP than at SC throughout the column (Fig. 8b), but this was due to the band being sampled for less time during this IOP by the UP MRR. The UP echo frequency decreased with height at a faster rate than at $\mathrm{SC}$, indicating stratiform precipitation at UP. The pattern in UP-SC CFAD difference (Fig. 8c) is similar to the one for the NR-SC difference (Fig. 7c), indicating greater reflectivity values throughout the column closer to the lakeshore.

IOP5 also featured substantial amounts of liquid water and water vapor (see Table 1). The MIPS MPR data revealed a maximum vertically integrated liquid water
(ILW) value of $1.95 \mathrm{~mm}$ during IOP5, which was measured at SC just minutes after all lightning activity had ended about $50 \mathrm{~km}$ to the northeast of the MIPS site. Although the microphysical variables observed at SC were favorable for lightning (e.g., graupel and liquid water), the storm radar characteristics observed near where lightning was observed are substantially different than at SC, indicating that the observations at SC may not be representative of the microphysical characteristics where lightning took place. The individual cells developed closer to the shoreline and moved to the eastnortheast from near SC to NR to UP, but their character changed (e.g., note how the maximum reflectivity values decreased in Fig. 5 as one moves inland).

\section{c. IOP7 (6-7 January 2014)}

\section{1) Mesoscale overview}

IOP7 began with disorganized convection around 2100 UTC 6 January 2014 (Figs. 9a,b). A synoptic-scale short-wave trough approached the region from the northwest between 0400 and 0600 UTC on 7 January, organizing and intensifying the convection into a coherent southwest-northeast-oriented LLAP band (Fig. 9c). After passage of the short wave, the band settled south and became a classic intense zonally oriented LLAP storm (Fig. 9d). The storm continued throughout the day and evening.

Per multiple proximity rawinsonde launches, the environmental $850-\mathrm{hPa}$ temperatures were between $-20^{\circ}$ and $-25^{\circ} \mathrm{C}$, with maximum sustained west-southwest 850-hPa winds of $25 \mathrm{~m} \mathrm{~s}^{-1}$ (Fig. 10;25 $\mathrm{m} \mathrm{s}^{-1}$ surface gusts 

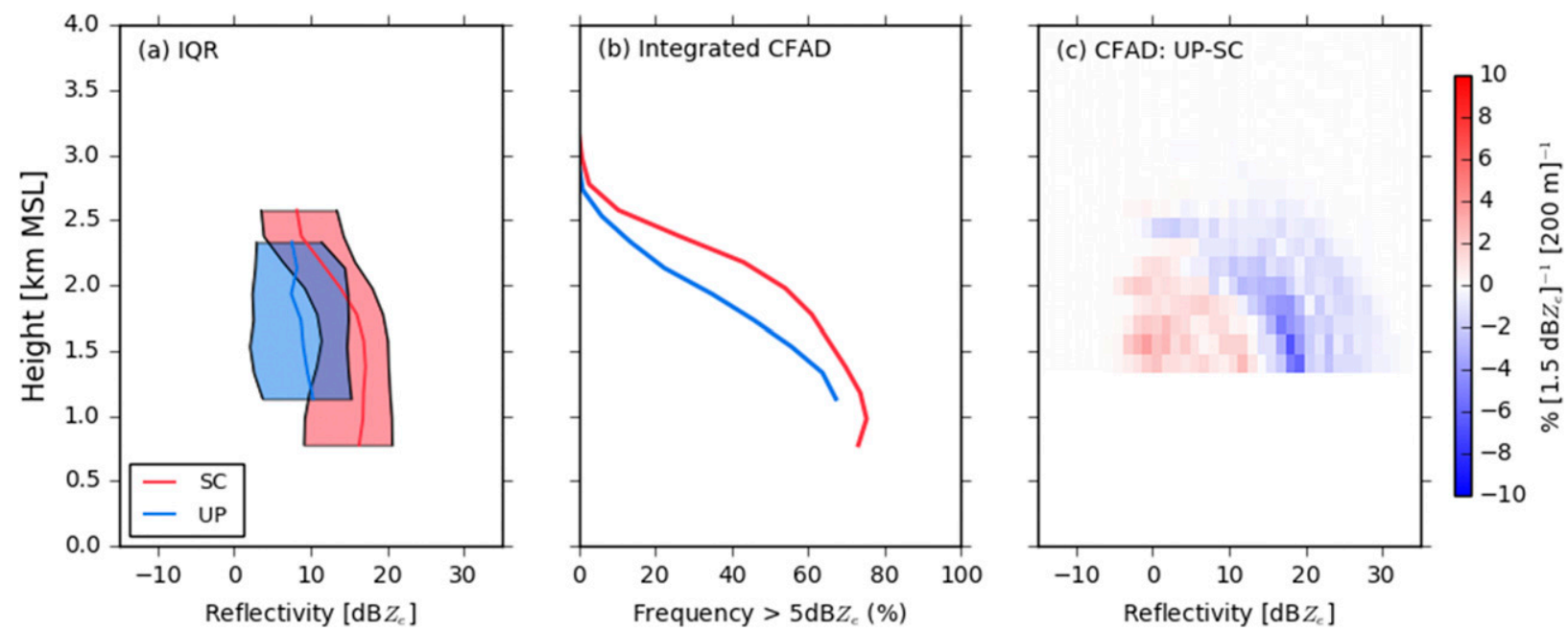

FIG. 8. As in Fig. 7, but for a comparison between the MRRs at SC and UP.

were also measured at Henderson Harbor, the western red star in Fig. 1). The lake-effect band moved southward, and the reflectivity gradient became very sharp along the northern band edge at 0500 UTC (Fig. 9c). This reflectivity gradient structure remained consistent for the next $3 \mathrm{~h}$, until 0800 UTC (Fig. 9d). A peak in lightning activity occurred during this period from 0630 to 0700 UTC. The charging layer was $2610 \mathrm{~m}$ deep (Table 1) and extended all the way to the surface, indicating very cold conditions (Fig. 10). This IOP also featured a very deep boundary layer with tops near $575 \mathrm{hPa}(\sim 4 \mathrm{~km} \mathrm{MSL})$. The calculated LI-CAPE was $1300 \mathrm{~J} \mathrm{~kg}^{-1}$, and the LI-EL was $4.5 \mathrm{~km} \mathrm{MSL}$, on the basis of an observed sounding at Darlington and a parcel initial temperature of $-6.4^{\circ} \mathrm{C}$.

\section{2) IOP7 STORM KINEMATICS, MICROPHYSICS, AND LIGHTNING}

IOP7 was the most prolific lightning-producing lakeeffect snowstorm observed during the OWLeS field project. Maximum reflectivity values ranged from 30 to $35 \mathrm{dBZ}$ according to KTYX data (Fig. 9). The NLDN detected a total of $25 \mathrm{CG}$ strokes (all with negative polarity except for 1 stroke) and 28 IC pulses. These strokes and pulses were grouped into 14 CG (1 positive; Table 2) and 6 IC flashes. This observation indicates that this storm had a low IC:CG ratio $(\mathrm{IC} / \mathrm{CG}<1)$ even if we account for the $50 \%-60 \%$ cloud-flash detection efficiency per Murphy and Nag (2015). This finding is similar to those of Bech et al. (2013), who observed similarly low IC/CG ratios during Mediterranean Sea cyclonic snowstorms. The lightning began at 0633 UTC and persisted for a little over $6 \mathrm{~h}$, ending at 1241 UTC. Mobile snow teams reported 15 occurrences of lightning and/or thunder, just over $50 \%$ of which overlapped with NLDN events (using a threshold time difference of $5 \mathrm{~min}$ and distance of $20 \mathrm{~km}$ between human and NLDN reports). Most of the observed lightning occurred well inland on the central and eastern Tug Hill plateau (Fig. 11).

MRR observations from the UP site (near where most of the lightning occurred) show that maximum updraft speeds exceeded $3 \mathrm{~m} \mathrm{~s}^{-1}$ (assuming snow terminal velocity of approximately $1 \mathrm{~m} \mathrm{~s}^{-1}$ ) at an elevation of $2.5 \mathrm{~km}$ in a region of weaker reflectivity (Figs. 12d, 13d) ( 0900-1000 UTC). Figure 12 shows that the IOP7 storm was substantially deeper than the IOP5 storm (echo tops near $3.5 \mathrm{~km}$ MSL for IOP7 vs $<3 \mathrm{~km}$ for IOP5). This is consistent with the sounding observations for each IOP. Maxima of MRR-measured reflectivity were greater and more frequent during IOP5, however, likely because of the frequent occurrence of graupel.

The core of the band was over the SC MRR site at 0700 UTC and over the NR site (about $30 \mathrm{~km}$ eastsoutheast of SC) $30 \mathrm{~min}$ later as the band moved southward (Figs. 9, 12). The portion of the band with KTYX reflectivity of greater than $20 \mathrm{dBZ}$ narrowed from a width of near $40 \mathrm{~km}$ at 0700 UTC to $15 \mathrm{~km}$ at 0900 UTC. This narrowing of the band was coincident with the strongest updrafts observed by any of the MRRs during this IOP at the UP site (Fig. 13d) as the core settled over the site from 0900 to 1100 UTC. Lightning was most frequent near the UP site around 0900 UTC (Fig. 13d).

The CFADs for IOP7 show a maximum in the median reflectivity profile at $2.4 \mathrm{~km}$ at NR (inland) and at $2.1 \mathrm{~km}$ MSL at SC (Fig. 14). The shapes of the profiles at both NR and SC were markedly different from IOP5. At NR, 
21:05:36 UTC

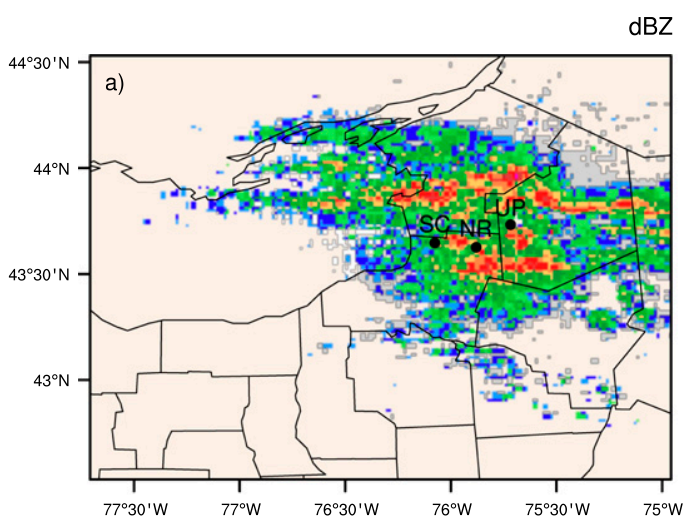

05:00:18 UTC

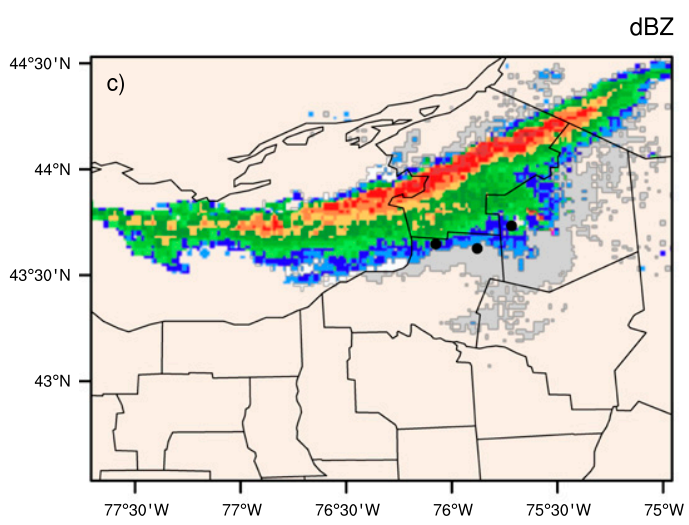

01:01:05 UTC

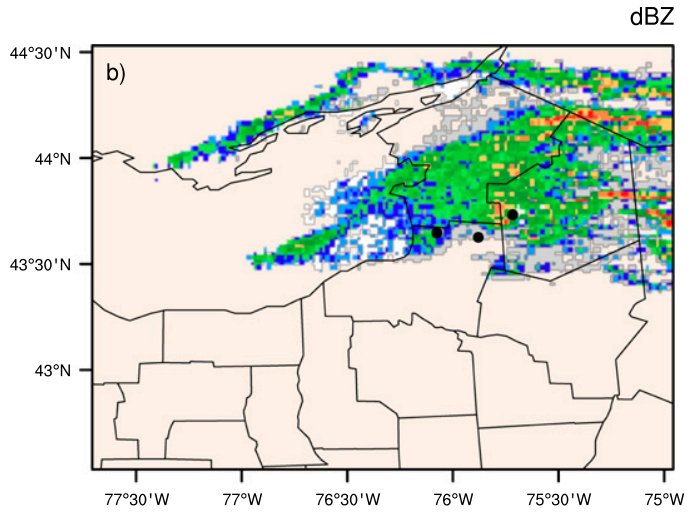

08:02:48 UTC

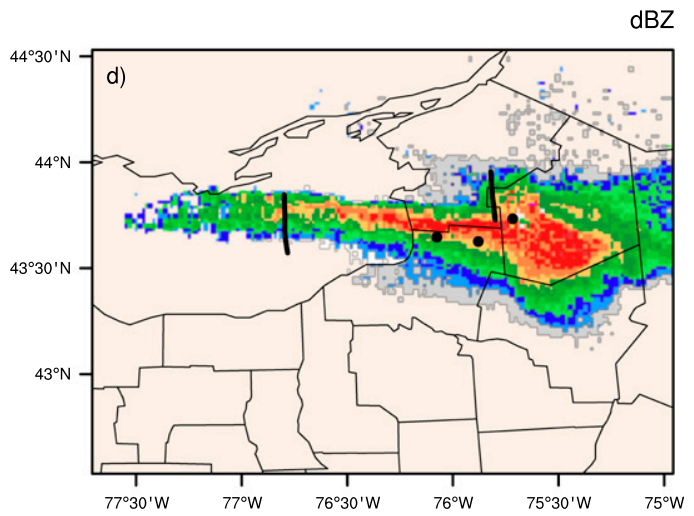

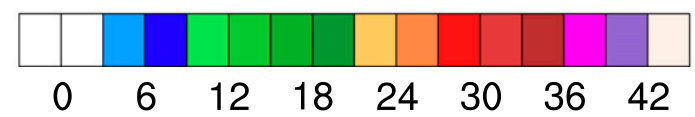

FIG. 9. As in Fig. 2, but for 6-7 Jan 2014 (IOP7). The UWKA transects discussed in the text are shown in (d) as black segments: the lake and inland legs, as shown in Figs. 17 and 18, below).

the median values increased with decreasing height from storm top to $2.4 \mathrm{~km}$ (suggesting hydrometeor growth), then rapidly decreased to a height of $2 \mathrm{~km}$ MSL, and then increased again toward the ground. The overall shape of the SC profile was similar to NR, with local minima and maxima in median reflectivity occurring at elevations that were about $300 \mathrm{~m}$ lower than at NR. These profiles are more difficult to interpret than the profiles observed during IOP5, perhaps reflecting the interaction with a synoptic feature during IOP7. The maximum median reflectivities were $18 \mathrm{~dB}_{e}$ at $\mathrm{SC}$ and $13 \mathrm{~dB} Z_{e}$ at NR (similar to IOP5). The integrated CFAD (Fig. 14b) is also different from that for IOP5. The NR data show more frequent echoes to $2.3 \mathrm{~km}$ MSL (vs $1.9 \mathrm{~km}$ for IOP5). Hence, the stratiform precipitation processes at NR likely extended through a deeper layer from the ground up relative to IOP5. Also, in contrast to IOP5, the difference CFAD between the NR and SC sites did not have a clear dipole (Fig. 14c), likely because of the non-steady-state nature of the band during IOP7. Despite the lack of a coherent dipole, there was a clear increase in weak reflectivity $\left(\sim 10 \mathrm{~dB} Z_{e}\right)$ throughout the lowest $1 \mathrm{~km}$ of the storm at NR, indicating more frequent stratiform precipitation. The interaction with the synoptic-scale short wave between 0500 and 0800 UTC 7 January likely contributed substantially to the differences between IOP5 and IOP7 and makes a direct comparison between these IOPs less clear.

The CFAD comparison between the UP (the MRR that was closest to the majority of lightning flashes; Fig. 11) and SC MRRs reveals that the reflectivity structure was much weaker inland (Fig. 15). The 


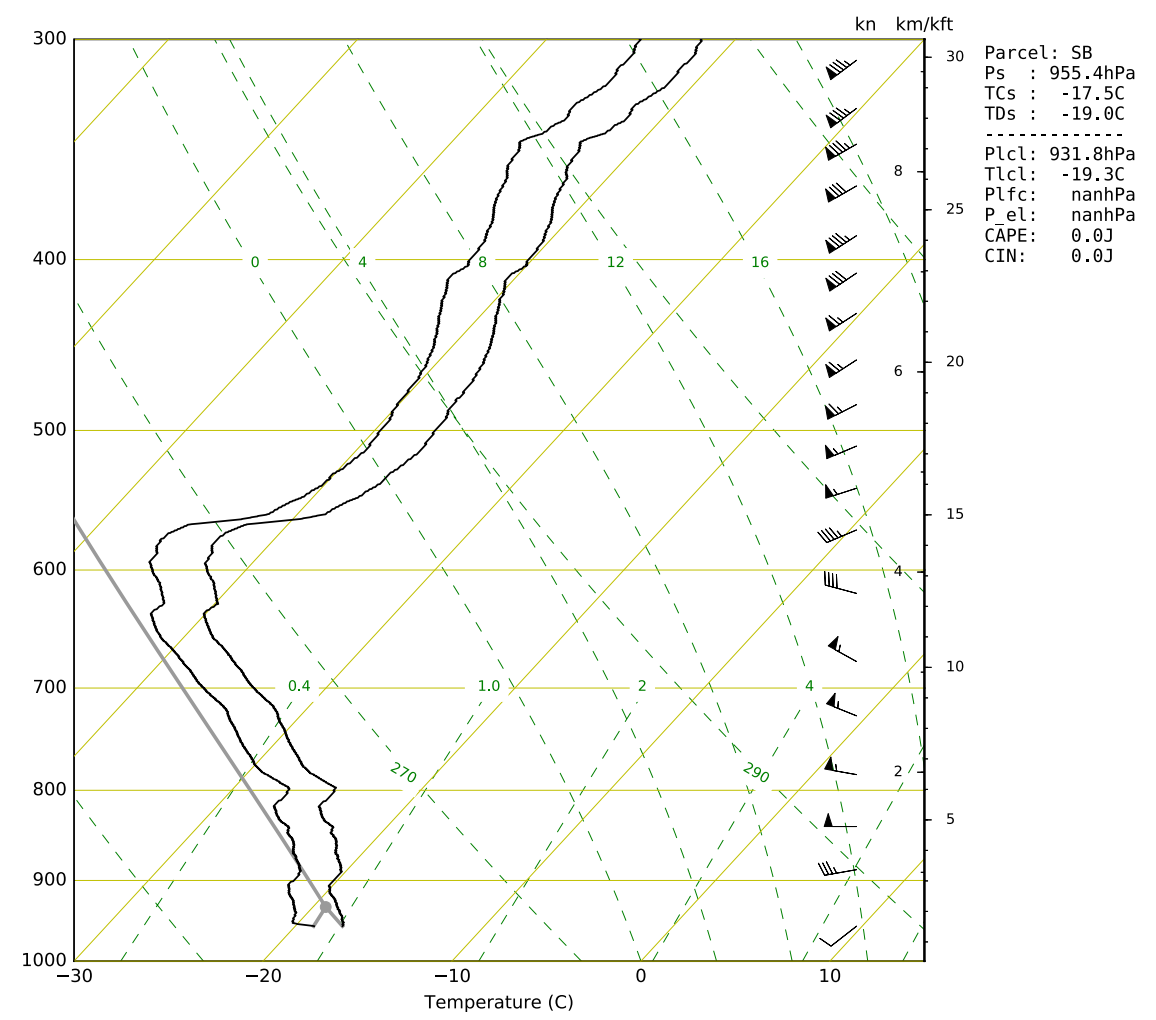

FIG. 10. As in Fig. 3, but for 0815 UTC 7 Jan 2014 (IOP7) at NR (in the band; refer to Fig. 9d), approximately $30 \mathrm{~km}$ from the area of most-dense lightning occurrence.

interquartile ranges do not overlap throughout one-half of the storm depth (Fig. 15a). Similar to the situation for IOP5, the band was not sampled for as long of a duration by the UP MRR (cf. Figs. 12b-d), but when the storm was over the UP station it was clearly a weaker part of the lake-effect band.

To explore the overlake vertical structure of IOP7, we use UWKA radar data from a flight leg (shown in Fig. 9) sampled between 1348 and 1354 UTC $(\sim 1 \mathrm{~h}$ after the lightning had ended). The band was narrower: $<20$ versus $\sim 40 \mathrm{~km}$ (using the $20-\mathrm{dB} Z$ contour from KTYX) and was oriented more from the southwest as compared with its west-northwest structure when the lightning began ( $\sim 0700$ UTC; cf. Figs. 16 a and $16 \mathrm{c})$, but was similar in structure in comparison with that when the lightning ended (1240 UTC; cf. Figs. 16b and 16c). Despite these structural differences, we believe a qualitative analysis likely provides some additional insight into the kinematics and microphysics of the lightningproducing storm as one moves from over the lake to inland and can be used to complement the in situ data available in closer proximity to the lightning. For the southern part of the storm $(y>20 \mathrm{~km}$ in Fig. 17), the velocity data suggest low-level small-scale turbulence indicative of fluxes off the unstable lake. In addition, strong updrafts $\left(\sim 5 \mathrm{~m} \mathrm{~s}^{-1}\right)$ appear to be correlated with local reflectivity minima throughout the band, suggesting precipitation lofting. Moderate updrafts appear to be correlated with enhanced reflectivity, suggesting precipitation growth. Between $y=5$ and $10 \mathrm{~km}$, near the northern part of the band, there was a distinct core associated with a broader area of upward vertical velocity with higher LWC and a clear signature of weaker reflectivity in the core of the band, with enhanced reflectivity on the edges (i.e., a bounded weak-echo region). Supercooled liquid water is indicated to be near cloud top at $y=7 \mathrm{~km}$ on the basis of the rapid lidar extinction below cloud top (not shown). Substantial localized LWC values $>0.4 \mathrm{~g} \mathrm{~m}^{-3}$ were present in this same location over a horizontal distance of $\sim 1.5 \mathrm{~km}$ (Fig. 17). Throughout the transect, reflectivity decreased toward the ground below $\sim 0.5 \mathrm{~km} \mathrm{MSL}$, suggesting lowlevel sublimation. The 1429-1434 UTC north-south flight leg (Figs. 9d, 16d, and 18) observed the band at a location nearer to where the lightning occurred $\sim 2 \mathrm{~h}$ earlier. According to KTYX radar data, the band was generally consistent in structure and location as compared with the observations from the earlier flight discussed (Fig. 16). The vertical velocities observed during this leg were generally weaker than those observed over 
TABLE 2. Lightning-flash characteristics for IOP5 (18 Dec 2013) and IOP7 (7 Jan 2014). The peak current is the largest current among all pulses in an IC flash or all strokes in a CG flash, and if a CG flash was composed of both pulses and strokes only stroke currents were used. The L/S/D classification represents the LTUL/SIUL/DPL flash (see the text for a description). The distance shown for a CG flash used the closest stroke within the flash to an anthropogenic structure.

\begin{tabular}{|c|c|c|c|c|c|}
\hline Date & Time (UTC) & Peak current (kA) & $\begin{array}{l}\text { Distance to the } \\
\text { nearest wind turbine }(\mathrm{km})\end{array}$ & $\begin{array}{l}\text { Distance to the } \\
\text { nearest other } \\
\text { antennas }(\mathrm{km})\end{array}$ & Lightning-flash type \\
\hline \multirow[t]{3}{*}{18 Dec 2013} & 2207 & -8.3 & 0.232 & $>0.30$ & $\mathrm{~L} / \mathrm{S} / \mathrm{D}$ \\
\hline & 2213 & -10.5 & 0.234 & $>0.30$ & $\mathrm{~L} / \mathrm{S} / \mathrm{D}$ \\
\hline & 2220 & -10.2 & 0.187 & $>0.30$ & $\mathrm{~L} / \mathrm{S} / \mathrm{D}$ \\
\hline \multirow[t]{20}{*}{7 Jan 2014} & 0634 & 11.3 & 0.795 & $>0.30$ & $\mathrm{IC}$ \\
\hline & 0636 & -10.7 & 0.202 & $>0.30$ & $\mathrm{IC}^{*}$ \\
\hline & 0653 & -17.3 & 12.092 & $>0.30$ & CG \\
\hline & 0653 & 15.6 & 22.164 & $>0.30$ & CG \\
\hline & 0653 & -9.0 & 24.932 & $>0.30$ & CG \\
\hline & 0653 & 23.4 & 48.726 & $>0.30$ & IC \\
\hline & 0821 & -22.2 & 6.455 & $>0.30$ & CG \\
\hline & 0842 & -12.9 & 0.178 & $>0.30$ & $\mathrm{~L} / \mathrm{S} / \mathrm{D}$ \\
\hline & 0842 & -49.6 & 5.836 & $>0.30$ & $\mathrm{CG}$ \\
\hline & 0857 & -10.3 & 6.662 & $>0.30$ & CG \\
\hline & 0859 & -13.7 & 0.193 & $>0.30$ & $\mathrm{IC}^{*}$ \\
\hline & 0906 & 37.3 & 5.836 & $>0.30$ & $\mathrm{IC}$ \\
\hline & 0913 & -10.2 & 0.210 & $>0.30$ & $\mathrm{~L} / \mathrm{S} / \mathrm{D}$ \\
\hline & 1009 & -33.4 & 10.276 & $>0.30$ & CG \\
\hline & 1015 & -13.1 & 0.237 & $>0.30$ & $\mathrm{~L} / \mathrm{S} / \mathrm{D}$ \\
\hline & 1052 & -8.2 & 0.180 & $>0.30$ & $\mathrm{~L} / \mathrm{S} / \mathrm{D}$ \\
\hline & 1056 & -22.5 & 6.477 & $>0.30$ & $\mathrm{CG}$ \\
\hline & 1104 & -13.0 & 0.167 & $>0.30$ & $\mathrm{~L} / \mathrm{S} / \mathrm{D}$ \\
\hline & 1122 & -9.3 & 8.080 & 0.21 & IC* \\
\hline & 1241 & -13.8 & 7.069 & 0.11 & $\mathrm{~L} / \mathrm{S} / \mathrm{D}$ \\
\hline
\end{tabular}

the lake, consistent with MRR observations. The inland cloud was deeper however. In general, LWC was lower than observed over the lake, although it was distributed over a larger spatial area. In similarity with the overlake transect, reflectivity generally decreased from near storm top to ground inland, even in the band core where heavy snow was reported at the surface.

IOP7 featured small amounts of ILW and water vapor relative to IOP5. A maximum ILW value of $0.24 \mathrm{~mm}$ (Table 1) occurred during IOP7 according to MIPS MPR data, which was measured during the time period of lightning, although the lightning occurred $50 \mathrm{~km}$ to the northeast.

Despite very cold conditions and a lack of graupel, the environmental and storm characteristics observed during IOP7 were still favorable for cloud electrification and lightning. For example, large LI-CAPE values, a high capping inversion and deep clouds, strong updrafts [stronger than those that occurred during IOP5 at the times of lightning (cf. Figs. $6 \mathrm{~d}$ and $13 \mathrm{~d}$ ), even though maximum updraft speeds via the MRR were similar; see Table 1], the presence of liquid water, and synoptic interaction are all conducive to lake-effect lightning. In similarity with IOP5, however, most of the lightning occurred in a more-stratiform region of the storm, well away from the core of the lake-effect convection. This result suggests that, in the storms discussed here, lightning is not occurring within the most active charging regions of the storm. In both IOPs, it is possible that the eastward advection of charge, combined with the elevated terrain of the Tug Hill plateau and the presence of a wind farm, helped to initiate lightning away from the convective core of the storm.

\section{d. A possible connection to wind farms?}

Past research has already shown a relationship between lightning and wind turbines (Wang and Takagi 2012; Montanyà et al. 2014; Warner et al. 2014). Multimegawatt wind turbines are tall structures with a higher probability than their surroundings of being struck by typical negative CG lightning. In addition, when towers and natural objects that rise more than $100 \mathrm{~m}$ above their surroundings are exposed to strong local electric fields under/within clouds, their tendency to initiate an upward-propagating leader and thus an upward flash is increased.

We explore a connection between the lightning during OWLeS and a wind farm by close inspection of NLDN data overlaid onto Google Earth imagery. The majority 


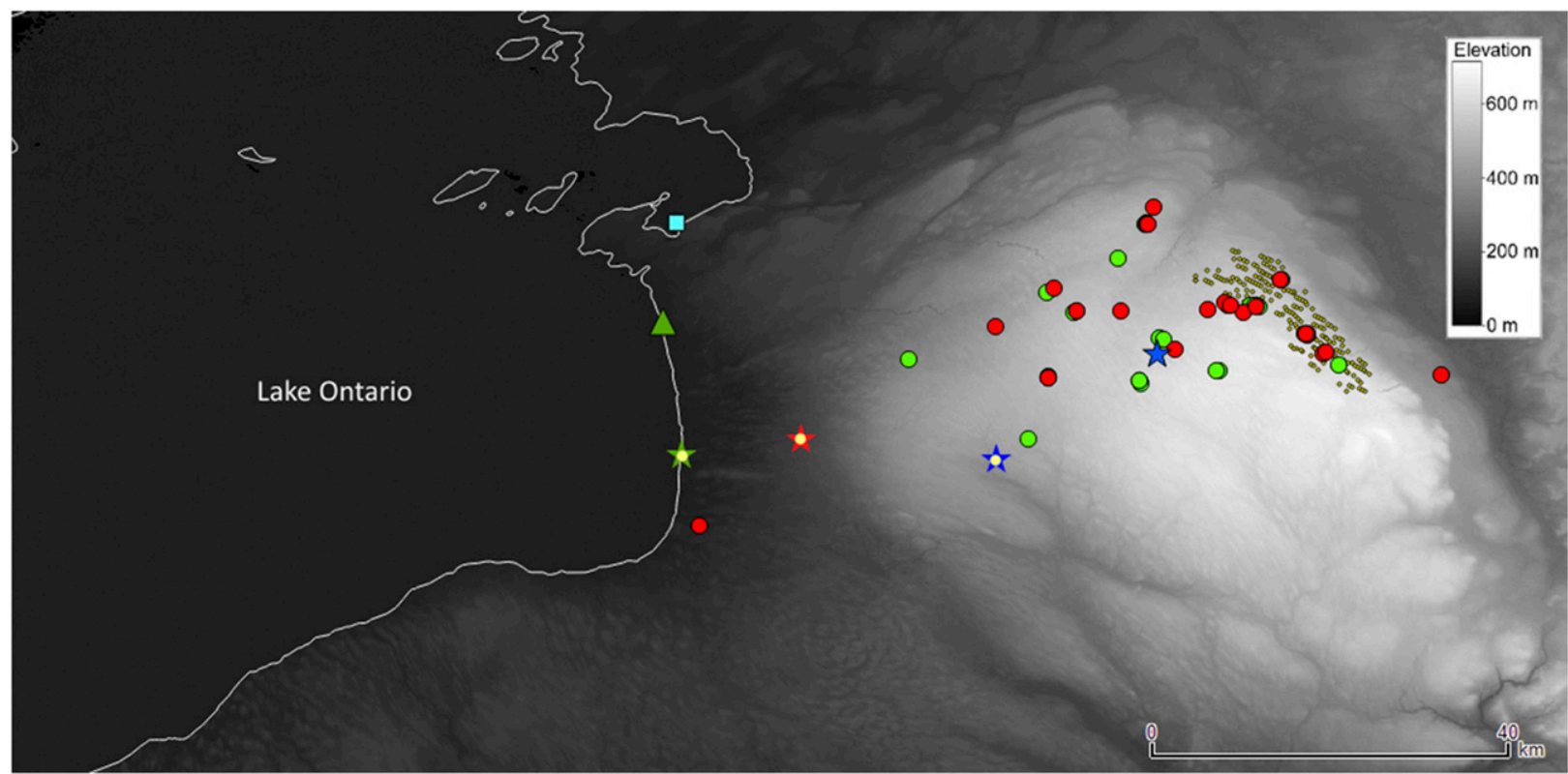

FIG. 11. As in Fig. 4, but for IOP7 (7 Jan 2014).

of these lightning flashes were located within 200-400 m of a nearby wind turbine at the Maple Ridge Wind Farm [most of the lightning in the climatological study of Steiger et al. (2009) occurred before farm construction]. Each wind tower hub is $79 \mathrm{~m}$ tall, with a rotor blade length of $40 \mathrm{~m}$ (for a total height of $119 \mathrm{~m}$ ). The turbine shuts down when the wind is higher than
$18.8 \mathrm{~m} \mathrm{~s}^{-1}$. Given the observed wind speeds, the turbines were likely rotating during most of IOP5 and IOP7. A check of the radial velocity data from nearby KTYX (within $15 \mathrm{~km}$ of the wind farm) for a few times during each of the IOPs showed a velocity couplet over some of the turbines, indicating that they were rotating (Toth et al. 2011).

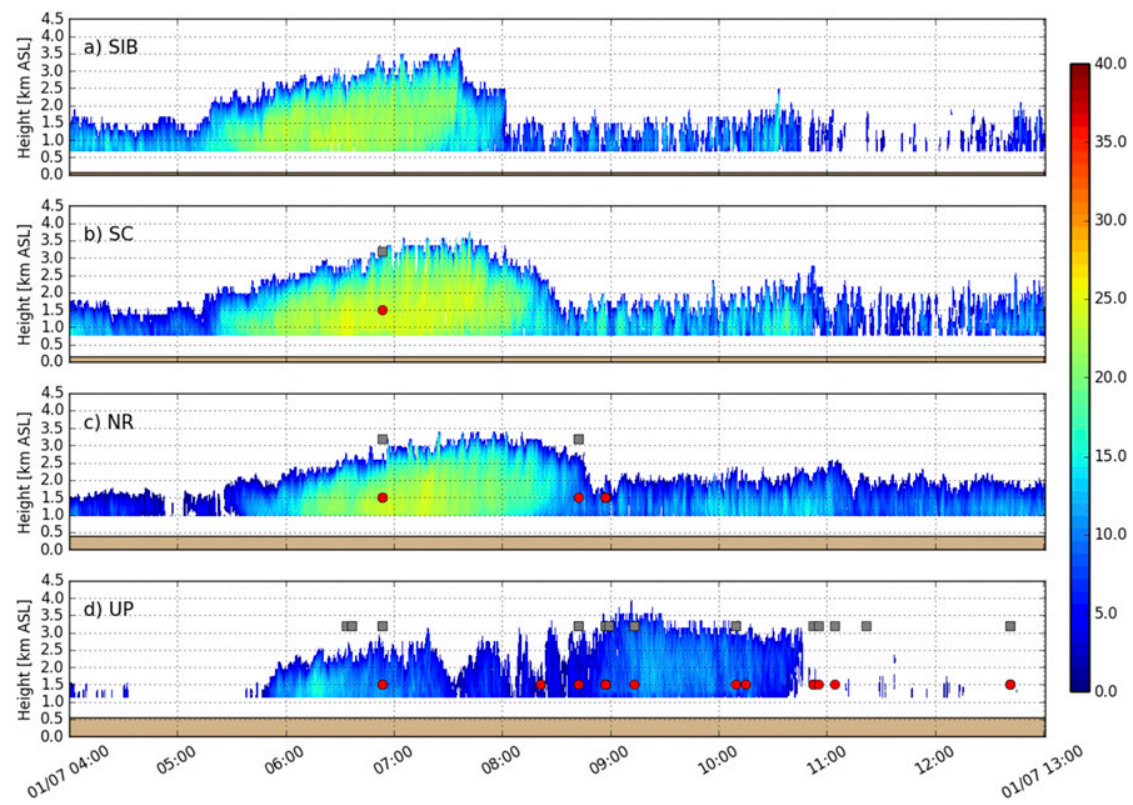

FIG. 12. As in Fig. 5, but for IOP7 (7 Jan 2014). The core of the lake-effect band moved over the MRRs between 0600 and 1000 UTC 7 Jan. 


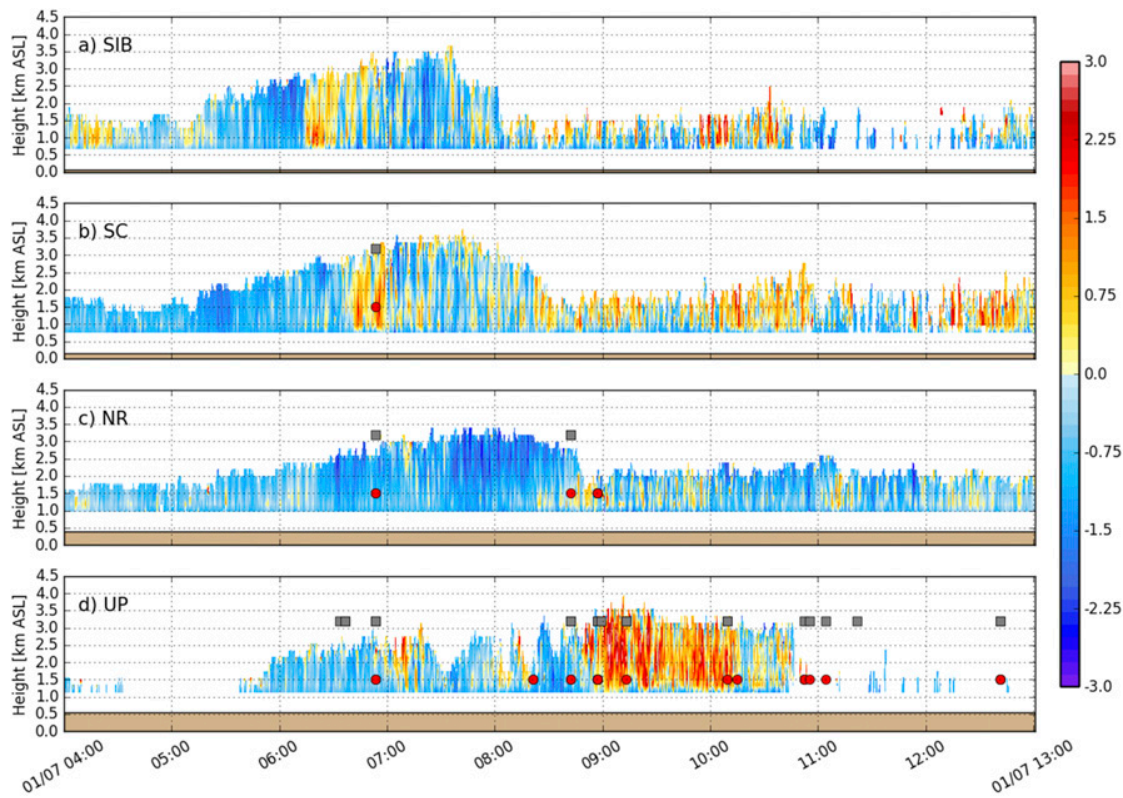

FIG. 13. As in Fig. 6, but for IOP7 (7 Jan 2014).

Using Google Earth, we determined the location of each wind turbine and then calculated the distance between each lightning stroke/pulse and the nearest turbine. If this distance was below the upper limit of the NLDN's location accuracy $(\sim 300 \mathrm{~m})$, then there was a distinct possibility that a turbine initiated the detected stroke/pulse. Because we did not have a database of all other man-made antennas besides the wind turbines in the region (e.g., television towers), we only recorded the distance from a stroke/pulse to these antennas (with the Google Earth "ruler" tool) if this distance was less than $300 \mathrm{~m}$. During IOP5, all four lightning strokes and pulses were located within $300 \mathrm{~m}$ of a turbine. During IOP7, 28\% of the CG strokes (of a total of
25 strokes) occurred within $300 \mathrm{~m}$ of a turbine and an additional $12 \%$ were within $300 \mathrm{~m}$ of other tall antennas. The remaining $60 \%$ of the CG strokes were mainly over wooded areas with no observable tall, anthropogenic structures. Thirty-six percent of IC pulses (of 28 total) detected during IOP7 were located within $300 \mathrm{~m}$ of a wind turbine, with an additional $11 \%$ within $300 \mathrm{~m}$ of a tower. Of all of the detected lightning strokes and pulses in this IOP (53 CG and IC), 32\% were within $300 \mathrm{~m}$ of a turbine and an additional $11 \%$ were within $300 \mathrm{~m}$ of a large antenna. Hence, $43 \%$ of this lightning may have been initiated by anthropogenic structures and may not have occurred but for human activity.
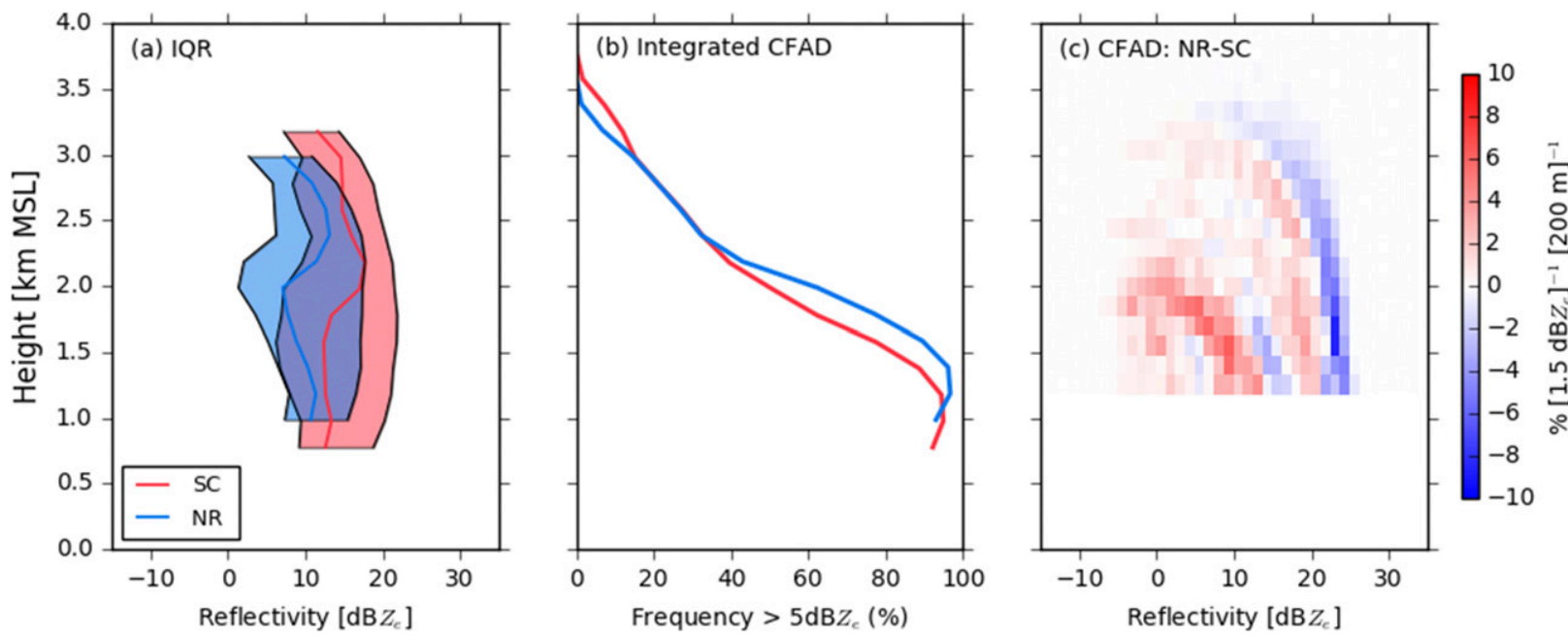

FIG. 14. As in Fig. 7, but for IOP7. 

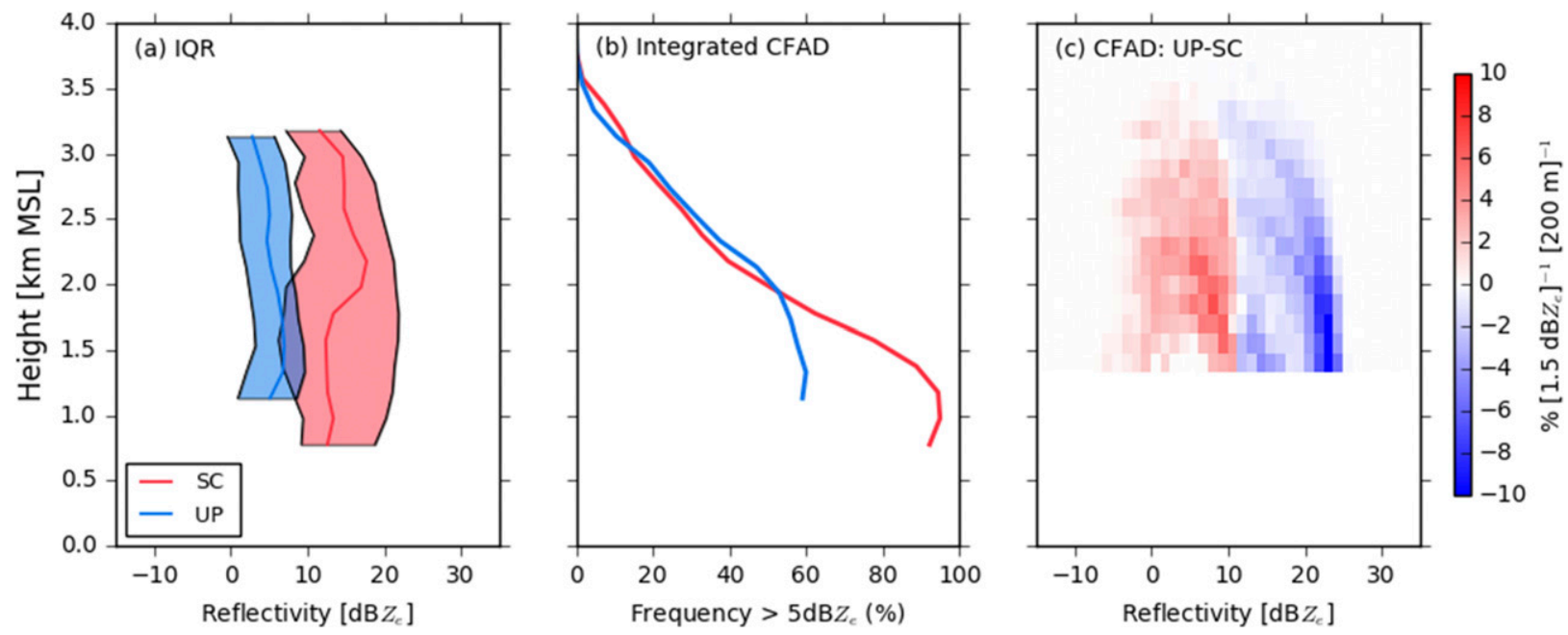

FIG. 15. As in Fig. 14, but for a comparison between the MRRs at SC and UP.

If no strokes/pulses within a flash (determined using the grouping algorithm that is described in section 2) occurred within $300 \mathrm{~m}$ of anthropogenic structures, the flash was categorized as a natural $\mathrm{CG}$ flash (if it contained $\geq 1$ CG stroke) or a natural IC flash (if the flash's events consisted of only IC pulses). The remainder of the CG flashes that had a stroke within $300 \mathrm{~m}$ of a wind turbine/antenna were likely LTUL (Warner et al. 2012), SIUL (Wang and Takagi 2012), or CG flashes that were a result of downward-propagating lightning (DPL) striking a tower (collectively referred to as LTUL/SIUL/DPL, or L/S/Ds in Table 2). Cummins and Murphy (2009) note that the NLDN can misdiagnose CG events as IC. Additional research by Mallick et al. (2014) shows that 3\% of CG strokes were misdiagnosed as IC discharges by the NLDN in their study. Because of this fact, flashes were diagnosed as a fourth category (IC*) when an IC flash had at least one pulse within $300 \mathrm{~m}$ of a wind turbine/antenna.

All three flashes during IOP5 were composed of LTUL/SIUL/DPL flashes (Tables 1 and 2). Hence, all of the lightning observed during IOP5 likely occurred because of anthropogenic structures. Three of the 20 flashes during IOP7 were categorized as natural IC flashes, 8 were natural CG, and 6 were LTUL/SIUL/ DPL flashes. The remaining three flashes were of the IC* type. This indicates that close to one-half of the IOP7 flashes were likely due to human activity.

\section{Discussion}

Results from previous studies (e.g., Moore and Orville 1990; Steiger et al. 2009) on environments supportive of lake-effect lightning suggest that IOP5 had more favorable conditions in some respects for lightning than did IOP7. IOP5 had greater ILW, more graupel, and a deeper charging layer from $-5^{\circ}$ to $-40^{\circ} \mathrm{C}$ than did IOP7 (Table 1). In addition, the ground temperatures were well below freezing during IOP7, with the $-10^{\circ} \mathrm{C}$ isotherm below ground in contrast to at $1.2 \mathrm{~km}$ AGL during IOP5. Kitagawa and Michimoto (1994) found that colder environments are less favorable for lightning during convective snowfall in the Hokuriku District of Japan; in that study no lightning flashes were observed when the altitude of the $-10^{\circ} \mathrm{C}$ isotherm was below $1.4 \mathrm{~km}$.

The mean particle vertical velocities across all MRR sites for all sample times and all heights during IOP5 and IOP7 were -0.93 and $-0.74 \mathrm{~m} \mathrm{~s}^{-1}$, respectively. The median values, however, were similar $\left(-0.85\right.$ and $\left.-0.86 \mathrm{~m} \mathrm{~s}^{-1}\right)$. The velocity standard deviation was greater for IOP7 $\left(0.86\right.$ vs $\left.0.64 \mathrm{~m} \mathrm{~s}^{-1}\right)$. The velocity values are negative because of the fall velocity of the ice particles and were likely greater in magnitude in IOP5 because of the greater occurrence of graupel. Hence, it is difficult to determine whether the downward particle motion was weaker on average during IOP7 because the updrafts, which were a part of the mean particle motion, were stronger in IOP7 or because the heavier graupel somewhat negated updraft speeds in IOP5, resulting in stronger mean downward motion. The mean MRR reflectivity of the IOP5 storm was greater than that for IOP7 (12 vs $\left.10 \mathrm{~dB} Z_{e}\right)$, possibly because of the December storm's graupel production.

CFADs from IOP5 and IOP7 (e.g., Figs. 7 and 14) show that the IOP7 storm was deeper and had a larger maximum interquartile range (by $6 \mathrm{~dB} Z_{e}$, using the NR site). IOP5 had distributions similar to that described by Minder et al. (2015) as the reflectivity increased with 
07:00:06 UTC

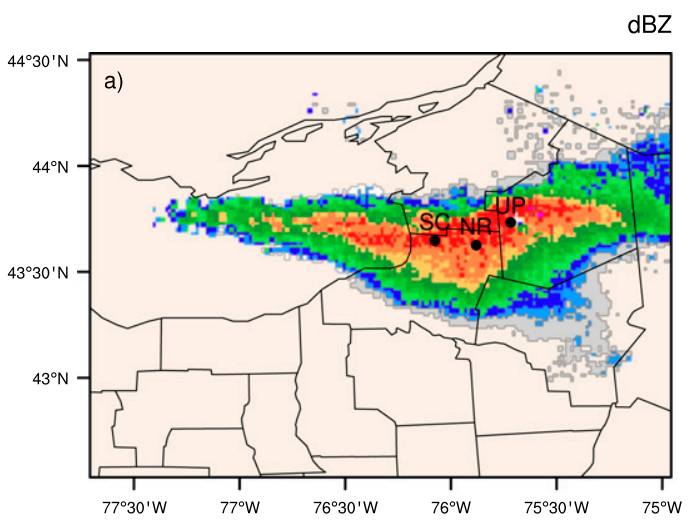

13:53:11 UTC

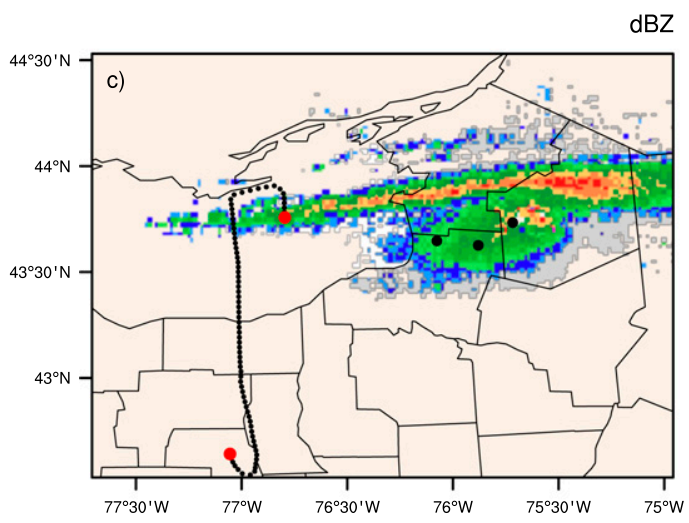

12:44:39 UTC

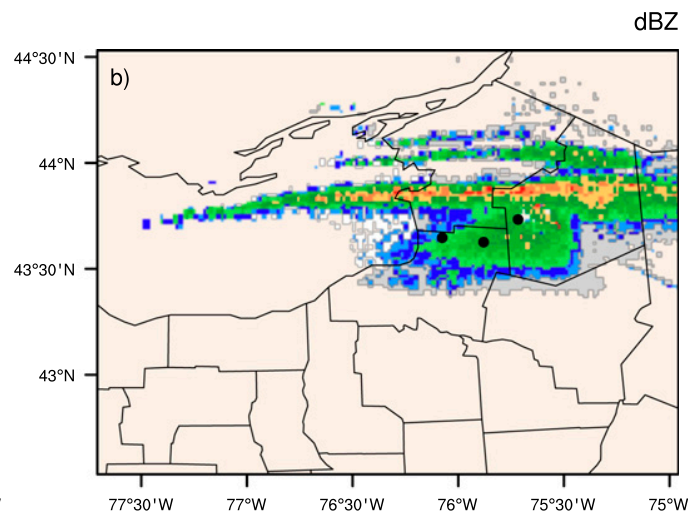

14:33:08 UTC

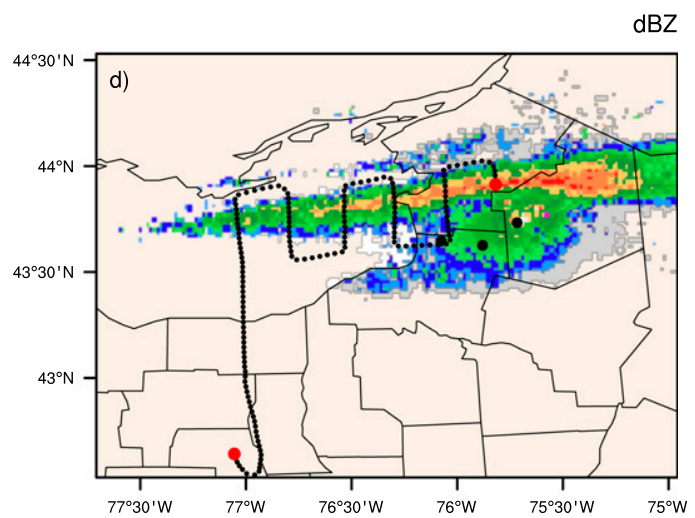

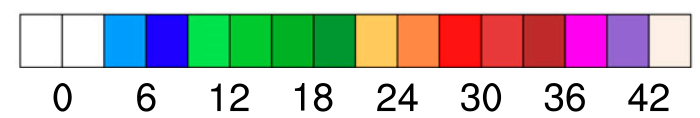

FIG. 16. KTYX base reflectivity for (a) 0700 UTC (near the time of lightning initiation for the event), (b) 1245 UTC (near the time when lightning ended), (c) 1353 UTC, and (d) 1433 UTC 7 Jan 2014. The UWKA track up to each time is shown in (c) (the start of the leg shown in Fig. 17, below) and (d) (the start of the leg shown in Fig. 18, below).

decreasing altitude to the ground, implying precipitation growth through the column, at the NR/inland site. The IOP7 CFAD shows a very different distribution that cannot be explained well at this time and possibly resulted from the passage of a synoptic trough. A comparison of Figs. $14 \mathrm{~b}$ and $7 \mathrm{~b}$ suggests a deeper layer of stratiform precipitation processes at the NR site during IOP7 than during IOP5. The top height to where the total frequency of echoes $>5 \mathrm{~dB} Z_{e}$ was greater at NR than at SC from the ground up was higher during IOP7 than during IOP5 (1.3 vs $0.9 \mathrm{~km}$ above radar level at NR) and comprised a slightly greater percentage of storm depth at NR during IOP7 (52\% vs $50 \%$ using the height at which the frequency $=0$ in Figs. $7 \mathrm{~b}$ and $14 \mathrm{~b}$ to define storm top). It is not intuitive that the greatest amount of observed lightning occurred in the IOP (IOP7) and nearest the site (NR) with radar reflectivity characteristics that are indicative of stratiform precipitation processes.

We propose that IOP7 had more lightning than the other lake-effect thunderstorms observed during OWLeS because of a very deep boundary layer. Although synoptic forcing largely caused the deep boundary layer, we speculate that the depth of the boundary layer may have been increased by an upwind elevated mixed layer (possibly formed by the deep boundary layer mixing over the upper Great Lakes). A comparison between upwind and downwind soundings taken around Lake Ontario indicates that this lakemodified boundary layer traversed the stable surface 


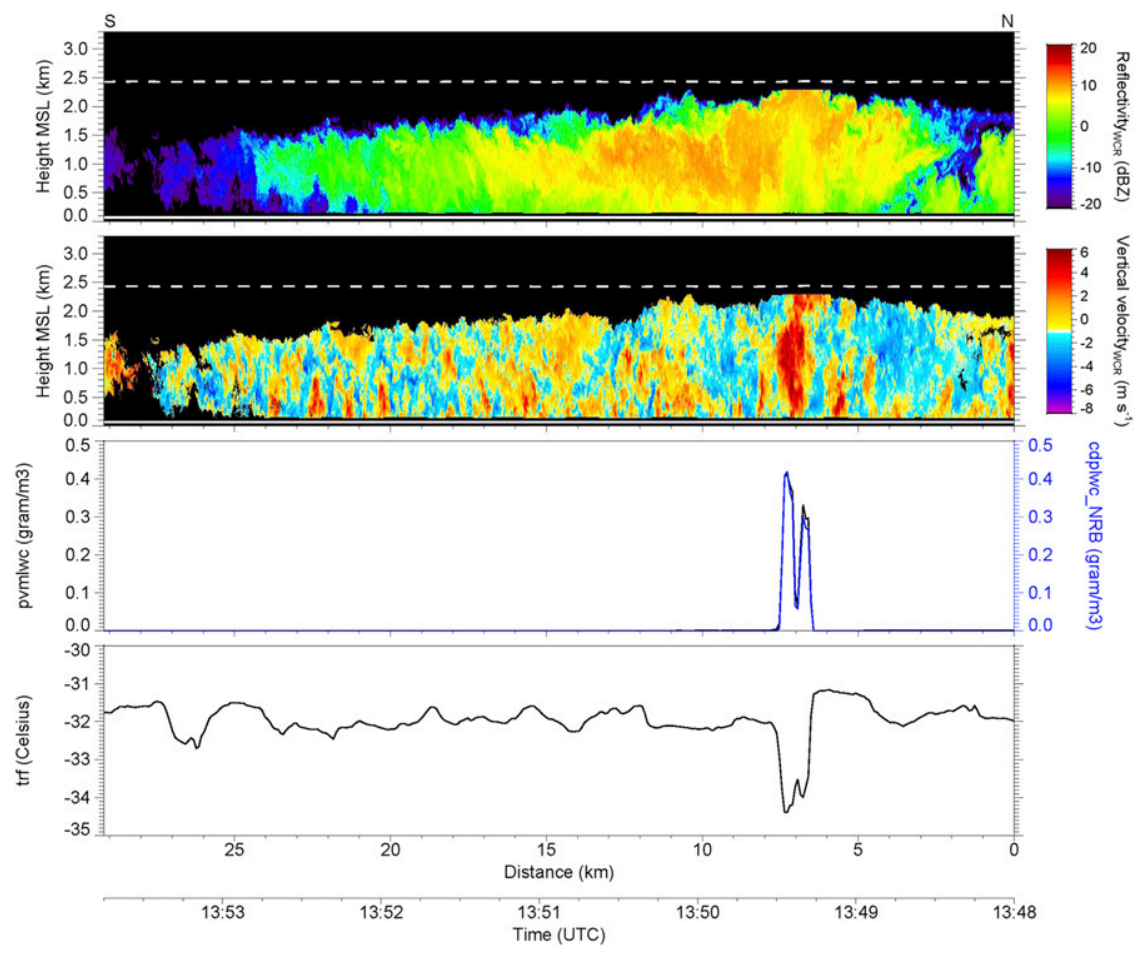

FIG. 17. UWKA data for (top) WCR reflectivity, (top middle) Doppler velocity (note that the $-1 \mathrm{~m} \mathrm{~s}^{-1}$ contour is assumed to be no vertical air motion to account for a typical terminal fall speed of snow), (bottom middle) LWC (black = PVM; blue $=$ CDP), and (bottom) ambient air temperature of a lake-effect snowband for 1348-1354 UTC 7 Jan 2014 (IOP7) over Lake Ontario (north-south cross section). The altitude of the craft is shown by the dashed line at $2.4 \mathrm{~km}$ MSL, with topography shown in black along the bottom of the top two panels. For geographical location, see the flight leg overlaid in Figs. 9d and 16c.

layer over the Canadian landmass between Lakes $\mathrm{Hu}-$ ron and Ontario and connected with the surface mixed layer over Lake Ontario. In addition to the deep boundary layer in the environment, storm electrification and lightning production during IOP7 were likely aided by the increased instability relative to IOP5 (a large temperature difference between the lake surface and the air of $T_{\text {Lake }}-T_{2 \mathrm{mAir}}>10^{\circ} \mathrm{C}$; LI-CAPE $>1000 \mathrm{~J} \mathrm{~kg}^{-1}$ during IOP7) along with strong and very gusty winds $\left(\sim 25 \mathrm{~m} \mathrm{~s}^{-1}\right.$ near the surface), which created very turbulent motions (e.g., Fig. 17) that helped to deepen the boundary layer and separate charge. Last, a comparison of Fig. 5 with Fig. 12 and Fig. 6 with Fig. 13 shows that IOP7 had broader, longer-lived areas of enhanced reflectivity and updrafts that can lead to more frequent hydrometeor collisions and electrical charging.

Takahashi et al. (1999) show that greater particle charging occurs near the $-20^{\circ} \mathrm{C}$ level in the winter thunderstorms they studied. This level was much closer to the ground ( $\sim 900 \mathrm{hPa}$; Fig. 10$)$ in IOP7 than in IOP5 ( $\sim 700 \mathrm{hPa}$; Fig. 3). This situation supports the finding of more CG flashes (and hence more total lightning) during
IOP7 because the charge regions were likely closer to the ground, enhancing the electric field between ground and cloud.

The strong surface winds observed during IOP7 may have also directly aided in discharging lightning near the Maple Ridge wind turbines via processes discussed by Montanyà et al. (2014). Strong winds/rotating turbines can remove corona charge around the turbine tips, enhancing the electric field. Also, Williams (1988) proposes that blowing snow can generate positive space charge within the surface layer.

A possible mechanism explaining the preference for lightning to occur inland within the more stratiform precipitation rather than over the lake is shown in Fig. 19. In this mechanism, charge separation (not yet strong enough to initiate lightning) occurs mostly over the eastern end of the lake, where the clouds are generally more turbulent and contain more liquid water and graupel. The overlake separated charge regions and the associated enhanced electric field between them are then advected inland (advection/persistence time of approximately $0.5 \mathrm{~h}$ using observed wind speeds at storm 


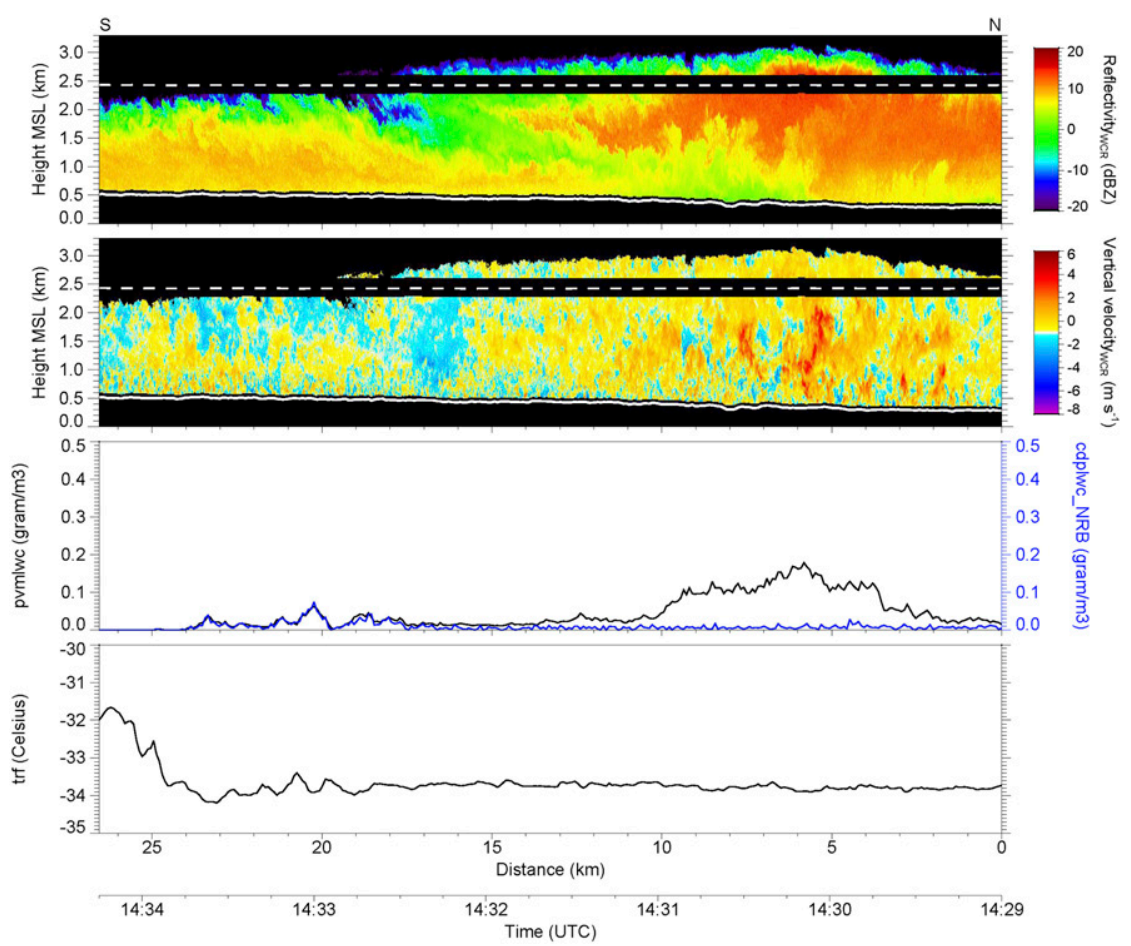

FIG. 18. As in Fig. 17, but for 1429-1434 UTC 7 Jan 2014 and over the Tug Hill plateau. See the flight leg in Figs. 9d and 16d.

midlevels and the distance to the lightning area from the lakeshore). At the local scale, the electric field, albeit a bit weaker as the charge regions likely become more diffuse as they are advected inland $\sim 30-50 \mathrm{~km}$, is enhanced as it approaches the wind turbines and the positive space charge generated near the surface as proposed by Williams (1988). This, in turn, initiates lightning, in effect discharging the strong vertical electric fields along the band from near the shore inland to the Tug Hill plateau. Inland lightning events that are not associated with anthropogenic structures can be associated with taller trees on top of the higher terrain.

To investigate this possible mechanism further, more observational studies are needed. For example, facilities such as the Lightning Mapping Array (Rison et al.1999), surface electric-field mills, and electric-field soundings (e.g., Stolzenburg et al. 1998) would give further support or rejection to this hypothesis. In addition, the climatological description of Steiger et al. (2009) should be updated and segregated for a period before and after the wind farm was constructed to determine whether and how wind farms influence the climatological occurrence of lake-effect lightning. A preliminary analysis using two short periods (six seasons before construction and six seasons after the construction of the Maple Ridge Wind Farm) suggests a shift to more inland lightning nearer to the wind farm after it was built (not shown). We plan to show this analysis in a subsequent paper.

\section{Conclusions}

Lightning flashes during lake-effect snowstorms are relatively unexpected as compared with occurrences during summertime storms (e.g., see the video of lightning that was made by one of the OWLeS student field teams that is available in the online supplemental material). The environment in which these flashes occur can be used to study the minimum threshold needed for the initiation of lightning (storms with very low flash rates). Because lake-effect storms occur multiple times every winter season across the Great Lakes and lakeeffect thunderstorms also occur every season, these storms provide a dependable laboratory for such studies.

The results presented in this paper represent the next logical step to understanding the lake-effect lightning story that was first detailed by studies such as Moore and Orville (1990) and Steiger et al. (2009), who did not have the type of high-resolution observational data that was collected during the OWLeS project. The observations for the two lake-effect thundersnow events discussed here led to some answers but also to many questions. 


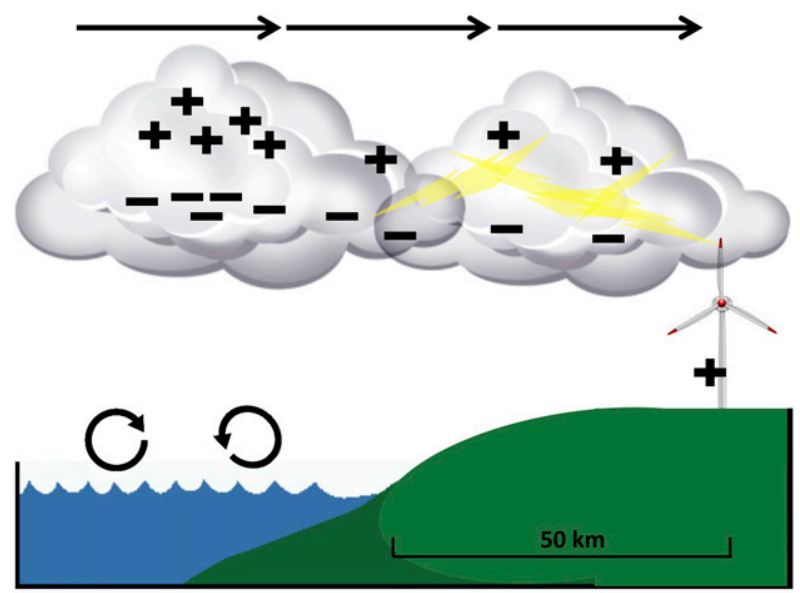

FIG. 19. A schematic that shows how charge separation during a lake-effect storm develops over the lake (where more LWC and stronger vertical motions exist) but does not result in electrical breakdown until this area of charge separation moves over a tall, anthropogenic structure such as a wind turbine that is present in the cases in this paper. Note that the turbine is not drawn to scale. The regions of positive and negative space charge are assumed on the basis of previous studies relating temperature and LWC values to charging of graupel and ice crystals (MacGorman and Rust 1998, 65-70).

- As compared with the IOP with less lightning (IOP5), IOP7 was characterized by a deeper boundary layer, greater instability, less cloud liquid water content, fewer surface graupel reports, and a charging layer with lesser depth. IOP7 also had more stratiform radar reflectivity characteristics. Our results suggest that a wider range of conditions favorable for lake-effect lightning exists than had been previously thought, particularly when combined with the influence of taller structures such as wind turbines and other anthropogenic towers.

- Updraft air speeds were generally estimated to be between 1 and $5 \mathrm{~m} \mathrm{~s}^{-1}$ (using 10-s average observations; MRR), with maxima approaching $10 \mathrm{~m} \mathrm{~s}^{-1}$ (1-saverage observations; UWKA-WCR). The strongest updrafts were generally over the lake, near the eastern Lake Ontario shoreline, and weakened substantially farther inland. The greatest updrafts observed during IOP7 by the MRRs were over the upper Tug Hill plateau, however. Also, the updraft region was wider inland (cf. Figs. 17 and 18).

- In IOP7, local LWC was highest in the updraft regions of the cells within LLAP lake-effect storms near the lake. Values were lower $\left(0.1-0.2 \mathrm{~g} \mathrm{~m}^{-3}\right)$ farther inland nearer the lightning-active portion of the storm. Maximum vertically integrated LWC values were approximately 2.0 and $0.25 \mathrm{~mm}$ during the 18 December 2013 and 7 January 2014 lightning IOPs (5 and 7), respectively, at a site $15 \mathrm{~km}$ inland within the core of the band (Sandy Creek).

- The cases discussed in this paper are outliers when compared with the climatological description in Steiger et al. (2009), in that lightning in these storms occurred inland. A hypothesis that helps to explain the observations made during this project is that enhanced convective activity over the lake is sufficient to separate electrical charge but is not sufficient to initiate lightning over the lake. These separated charge regions are then advected tens of kilometers inland, where the electrical field is locally strengthened and is discharged by large, anthropogenic structures (e.g., wind turbines and television towers) and perhaps by tall trees in the Tug Hill plateau region. We speculate that there are two modes of lake-effect lightning: one in which tall structures are not required [e.g., this would explain most of the lightning in Steiger et al. (2009)] and one in which conditions are marginal and tall structures initiate lightning that otherwise would not have occurred.

- Most of the OWLeS lightning was cloud-to-ground (20 of 26 NLDN flashes), and a large fraction of the flashes in these low-flash-rate storms are likely due to the presence of anthropogenic structures (e.g., all 3 flashes in IOP5 and 9 of 20 flashes in IOP7). We cannot compare this ratio with previous climatological data, because in-cloud lightning detection has been a recent advance for operational networks. Observations from the newly launched Geostationary Lightning Mapper on the GOES-16 will give more information about the total $(\mathrm{CG}+\mathrm{IC})$ lightning, including the areal extent of the flashes, in these storms.

- The next logical step to test these ideas more is to observe the charge structure in LLAP bands with electrical balloon soundings (e.g., Stolzenburg et al. 1998) and total-lightning-mapping networks (e.g., the Lightning Mapping Array; Rison et al. 1999). The electrical charge structure within lake-effect storms is largely unknown.

Acknowledgments. We thank Dr. Robert Ballentine of the SUNY Oswego meteorological faculty for first suggesting a possible connection between lightning occurrences during IOP5 and IOP7 and the nearby Maple Ridge Wind Farm. Also, our gratitude is given to Dr. Steven Skubis of Oswego for computer programming assistance. Bart Geerts and his graduate students provided Figs. 17 and 18. We thank Vaisala, Inc., for providing the NLDN data. Kudos are given to all of the OWLeS participants for their hard work and dedication in collecting (in sometimes very harsh conditions) so 
much relevant data with which to work, especially the North Redfield sounding launchers from the University of Utah! The National Center for Atmospheric Research (NCAR) Earth Observing Laboratory (EOL) maintains the OWLeS data repository, and all of the OWLeS datasets are available online from the NCAR EOL site (http://data.eol.ucar.edu/master_list/?project= OWLeS). The material in this paper is based upon work supported by the National Science Foundation under Grant AGS 1258894.

\section{REFERENCES}

Bech, J., N. Pineda, T. Rigo, and M. Aran, 2013: Remote sensing analysis of a Mediterranean thundersnow and low-altitude heavy snowfall event. Atmos. Res., 123, 305-322, https:// doi.org/10.1016/j.atmosres.2012.06.021.

Cummins, K. L., and M. J. Murphy, 2009: An overview of lightning locating systems: History, techniques, and data uses, with an indepth look at the U.S. NLDN. IEEE Trans. Electromagn. Compat., 51, 499-518, https://doi.org/10.1109/TEMC.2009.2023450.

$\longrightarrow,-$, E. A. Bardo, W. L. Hiscox, R. B. Pyle, and A. E. Piefer, 1998: A combined TOA/MDF technology upgrade of the U.S. National Lightning Detection Network. J. Geophys. Res., 103, 9035-9044, https://doi.org/10.1029/98JD00153.

Diendorfer, G., H. Pichler, and M. Mair, 2009: Some parameters of negative upward-initiated lightning to the Gaisberg Tower (2000-2007). IEEE Trans. Electromagn. Compat., 51, 443-452, https://doi.org/10.1109/TEMC.2009.2021616.

Karan, H., and K. Knupp, 2006: Mobile Integrated Profiler System (MIPS) observations of low-level convergent boundaries during IHOP. Mon. Wea. Rev., 134, 92-112, https://doi.org/ 10.1175/MWR3058.1.

Kingfield, D. M., K. M. Calhoun, and K. M. de Beurs, 2017: Antenna structures and cloud-to-ground lightning location: 1995-2015. Geophys. Res. Lett., 44, 5203-5212, https://doi.org/ 10.1002/2017GL073449.

Kitagawa, N., and K. Michimoto, 1994: Meteorological and electrical aspects of winter thunderclouds. J. Geophys. Res., 99, 10 713-10 721, https://doi.org/10.1029/94JD00288.

Kristovich, D. A. R., and Coauthors, 2017: The Ontario Winter Lake-Effect Systems field campaign: Scientific and education adventures to further our knowledge and prediction of lakeeffect storms. Bull. Amer. Meteor. Soc., 98, 315-332, https:// doi.org/10.1175/BAMS-D-15-00034.1.

Lu, W., D. Wang, Y. Zhang, and N. Takagi, 2009: Two associated upward lightning flashes that produced opposite polarity electric field changes. Geophys. Res. Lett., 36, L05801, https:// doi.org/10.1029/2009GL036598.

MacGorman, D. R., and W. D. Rust, 1998: The Electrical Nature of Storms. Oxford University Press, $422 \mathrm{pp}$.

Mallick, S., and Coauthors, 2014: An update on the performance characteristics of the NLDN. Preprints, 23rd Int. Lightning Detection Conf./5th Int. Lightning Meteorology Conf., Tucson, AZ, Vaisala, http://www.atmo.arizona.edu/students/courselinks/ spring17/atmo589/lecture_notes/lightning_location_NLDN/An Update_on_the_Performance_Characteris.pdf.

Market, P., C. Halcomb, and R. Ebert, 2002: A climatology of thundersnow events over the contiguous United States. Wea. Forecasting, 17, 1290-1295, https://doi.org/10.1175/15200434(2002)017<1290:ACOTEO>2.0.CO;2.
Michimoto, K., 1991: A study of radar echoes and their relation to lightning discharge of thunderclouds in the Hokuriku District. Part I: Observation and analysis of thunderclouds in summer and winter. J. Meteor. Soc. Japan, 69, 327-335, https://doi.org/ 10.2151/jmsj1965.69.3_327.

Minder, J. R., T. W. Letcher, L. S. Campbell, P. G. Veals, and J. W. Steenburgh, 2015: The evolution of lake-effect convection during landfall and orographic uplift as observed by profiling radars. Mon. Wea. Rev., 143, 4422-4442, https://doi.org/ 10.1175/MWR-D-15-0117.1.

Montanyà, J., O. Van der Velde, and E. R. Williams, 2014: Lightning discharges produced by wind turbines. J. Geophys. Res. Atmos., 119, 1455-1462, https://doi.org/10.1002/2013JD020225.

Moore, P. K., and R. E. Orville, 1990: Lightning characteristics in lakeeffect thunderstorms. Mon. Wea. Rev., 118, 1767-1782, https:// doi.org/10.1175/1520-0493(1990)118< 1767:LCILET>2.0.CO;2.

Murphy, M. J., and A. Nag, 2015: Cloud lightning performance and climatology of the U.S. based on the upgraded U.S. National Lightning Detection Network. Seventh Conf. on the Meteorological Applications of Lightning, Phoenix, AZ, Amer. Meteor. Soc., 8.2, https://ams.confex.com/ams/95Annual/ webprogram/Paper262391.html.

Niziol, T. A., W. R. Snyder, and J. S. Waldstreicher, 1995: Winter weather forecasting throughout the eastern United States. Part IV: Lake effect snow. Wea. Forecasting, 10, 61-77, https://doi.org/ 10.1175/1520-0434(1995)010<0061:WWFTTE $>2.0 . C O ; 2$.

Rakov, V. A., and M. A. Uman, 2003: Lightning: Physics and Effects. Cambridge University Press, $687 \mathrm{pp}$.

Rauber, R., and Coauthors, 2014: Stability and charging characteristics of the comma head region of continental winter cyclones. J. Atmos. Sci., 71, 1559-1582, https://doi.org/10.1175/ JAS-D-13-0253.1.

Rison, W., R. Thomas, P. Krehbiel, T. Hamlin, and J. Harlin, 1999: A GPS-based three-dimensional lightning mapping system: Initial observations in central New Mexico. Geophys. Res. Lett., 26, 3573-3576, https://doi.org/10.1029/1999GL010856.

Saunders, C. P. R., H. Bax-Norman, C. Emersic, E. E. Avila, and N. E. Castellano, 2006: Laboratory studies of the effect of cloud conditions on graupel/crystal charge transfer in thunderstorm electrification. Quart. J. Roy. Meteor. Soc., 132, 2653-2673, https://doi.org/10.1256/qj.05.218.

Schultz, D., 1999: Lake-effect snowstorms in northern Utah and western New York with and without lightning. Wea. Forecasting, 14, 1023-1031, https://doi.org/10.1175/1520-0434 (1999)014<1023:LESINU>2.0.CO;2.

Steiger, S., R. Hamilton, J. Keeler, and R. Orville, 2009: Lake-effect thunderstorms in the lower Great Lakes. J. Appl. Meteor. Climatol., 48, 889-902, https://doi.org/10.1175/2008JAMC1935.1.

, and Coauthors, 2013: Circulations, bounded weak echo regions, and horizontal vortices observed within long-lake-axisparallel-lake-effect storms by the Doppler on Wheels. Mon. Wea. Rev., 141, 2821-2840, https://doi.org/10.1175/MWR-D-12-00226.1.

Stolzenburg, M., W. Rust, B. Smull, and T. Marshall, 1998: Electrical structure in thunderstorm convective regions: 1. Mesoscale convective systems. J. Geophys. Res., 103, 14059-14078, https://doi.org/10.1029/97JD03546.

Takahashi, T., T. Tajiri, and Y. Sonoi, 1999: Charges on graupel and snow crystals and the electrical structure of winter thunderstorms. J. Atmos. Sci., 56, 1561-1578, https://doi.org/ 10.1175/1520-0469(1999)056<1561:COGASC >2.0.CO;2.

Toth, M., E. Jones, D. Pittman, and D. Solomon, 2011: DOW radar observations of wind farms. Bull. Amer. Meteor. Soc., 92, 987995, https://doi.org/10.1175/2011BAMS3068.1. 
Veals, P. G., and W. J. Steenburgh, 2015: Climatological characteristics and orographic enhancement of lake-effect precipitation east of Lake Ontario and over the Tug Hill Plateau. Mon. Wea. Rev., 143, 3591-3609, https://doi.org/10.1175/MWR-D-15-0009.1.

Wang, D., and N. Takagi, 2012: Characteristics of winter lightning that occurred on a windmill and its lightning protection tower in Japan. IEEJ Trans. Power Energy, 132, 568-572, https:// doi.org/10.1541/ieejpes.132.568.

_ - - T. Watanabe, H. Sakurano, and M. Hashimoto, 2008: Observed characteristics of upward leaders that are initiated from a windmill and its lightning protection tower. Geophys. Res. Lett., 35, L02803, https://doi.org/10.1029/2007GL032136.

Wang, Z., and Coauthors, 2012: Single aircraft integration of remote sensing and in situ sampling for the study of cloud microphysics and dynamics. Bull. Amer. Meteor. Soc., 93, 653-668, https://doi.org/10.1175/BAMS-D-11-00044.1.

Warner, T. A., K. L. Cummins, and R. E. Orville, 2012: Upward lightning observations from towers in Rapid City, South Dakota and comparison with National Lightning Detection Network data, 2004-2010. J. Geophys. Res, 117, D19109, https://doi.org/10.1029/2012JD018346.
, T. J. Lang, and W. A. Lyons, 2014: Synoptic scale outbreak of self-initiated upward lightning (SIUL) from tall structures during the central U.S. blizzard of 1-2 February 2011. J. Geophys. Res. Atmos., 119, 9530-9548, https://doi.org/ 10.1002/2014JD021691.

Williams, E. R., 1988: Anomalous electrification in winter storms. Preprints, 15th Conf. on Severe Local Storms, Baltimore, MD, Amer. Meteor. Soc., 304-308.

Yuter, S. E., and R. A. Houze Jr., 1995: Three-dimensional kinematic and microphysical evolution of Florida cumulonimbus. Part II: Frequency distributions of vertical velocity, reflectivity, and differential reflectivity. Mon. Wea. Rev., 123, 1941-1963, https://doi.org/10.1175/1520-0493(1995)123<1941: TDKAME $>2.0 . \mathrm{CO} ; 2$.

Zhou, H., G. Diendorfer, R. Thottappillil, H. Pichler, and M. Mair, 2012: Measured current and close electric field changes associated with the initiation of upward lightning from a tall tower. J. Geophys. Res., 117, D08102, https://doi.org/10.1029/2011JD017269.

Zipser, E. J., 1994: Deep cumulonimbus cloud systems in the tropics with and without lightning. Mon. Wea. Rev., 122, 1837-1851, https:// doi.org/10.1175/1520-0493(1994)122<1837:DCCSIT>2.0.CO;2. 